\title{
The Role Sol-gel Method and Doping Ba in the Drastic Reduction of the Annealing Time and the Improvement of the Coupling Between Grains of Bi1.6Pb0.4 Sr2-xBaxCa2Cu30y Superconductor
}

seyed ebrahim Mousavi Ghahfarokhi ( $\square$ musavi_ebrahim@yahoo.co.uk)

Department of Physics, Faculty of Science, Shahid Chamran University of Ahvaz, Ahvaz, Iran https://orcid.org/0000-0002-4495-5859

\section{Saeedeh Zamani}

university

\section{Research Article}

Keywords: Bi-based superconductor, Ba substitution, Magnetic susceptibility, XRD, Frequency, Sol-Gel

Posted Date: September 14th, 2020

DOI: https://doi.org/10.21203/rs.3.rs-74827/v1

License: (c) (i) This work is licensed under a Creative Commons Attribution 4.0 International License. Read Full License

Version of Record: A version of this preprint was published at Journal of the Australian Ceramic Society on February 1st, 2022. See the published version at https://doi.org/10.1007/s41779-021-00695-x. 


\title{
The role sol-gel method and doping $B a$ in the drastic reduction of the annealing time and the improvement of the coupling between grains of $\mathrm{Bi}_{1.6} \mathrm{~Pb}_{0.4} \mathrm{Sr}_{2-\mathrm{x}} \mathrm{Ba}_{\mathrm{x}} \mathrm{Ca}_{2} \mathrm{Cu}_{3} \mathrm{O}_{\mathrm{y}}$ superconductor
}

\author{
Seyed Ebrahim Mousavi Ghahfarokhi* and Saeedeh Zamani \\ Department of Physics, Faculty of Science, Shahid Chamran University of Ahvaz, Ahvaz, Iran \\ musavi_ebrahim@yahoo.co.uk \\ S.zamani91@yahoo.com
}

\begin{abstract}
In this study, the $\mathrm{Bi}_{1.6} \mathrm{~Pb}_{0.4} \mathrm{Sr}_{2-\mathrm{x}} \mathrm{Ba}_{\mathrm{x}} \mathrm{Ca}_{2} \mathrm{Cu}_{3} \mathrm{O}_{\mathrm{y}}$ superconductors with $\mathrm{x}=0.0,0.05,0.1,0.15$, $0.2,0.25$, and 0.3 were synthesized at annealing times of $32,48,64 \mathrm{~h}$ using a sol-gel method. Then, the effect of $\mathrm{Ba}$ doped, the annealing times, ac magnetic fields and frequencies in the improvement of the coupling between grains of the $\mathrm{Bi}_{1.6} \mathrm{~Pb}_{0.4} \mathrm{Sr}_{2-\mathrm{x}} \mathrm{Ba}_{\mathrm{x}} \mathrm{Ca}_{2} \mathrm{Cu}_{3} \mathrm{O}_{\mathrm{y}}$ (BPSBCC) superconductors were studied. In order to determine annealing temperature, TGA analysis of $\mathrm{x}=0.0$ was performed. The structural and ac magnetic susceptibility prepared samples were characterized using an X-ray diffraction, an ac susceptometer and scanning electron microscopy (SEM). The results of ac magnetic susceptibility and structural of the samples indicated that the improvement of the coupling between grains and the stability of the $\mathrm{Bi}_{1.6} \mathrm{~Pb}_{0.4} \mathrm{Sr}_{2-\mathrm{x}} \mathrm{Ba}_{\mathrm{x}} \mathrm{Ca}_{2} \mathrm{Cu}_{3} \mathrm{O}_{\mathrm{y}}$ superconductors with value of $\mathrm{x}=0.2$ at $845^{\circ} \mathrm{C}$ for $48 \mathrm{~h}$ have been increased.
\end{abstract}

Keywords: Bi-based superconductor; Ba substitution; Magnetic susceptibility; XRD; Frequency; Sol-Gel

PACS: $74.72 . \mathrm{Hs}$

\section{Introduction}

The high-temperature cuprate superconductors are classified into several categories such as $\mathrm{La}_{2-\mathrm{x}} \mathrm{Mn}_{\mathrm{x}} \mathrm{CuO}_{4}(\mathrm{LMCO}), \mathrm{YBa}_{2} \mathrm{Cu}_{3} \mathrm{O}_{4+\delta}(\mathrm{YBCO})$, based compounds $\mathrm{Bi}, \mathrm{Ti}, \mathrm{Hg}$ with the general formula $\mathrm{AM}_{2} \mathrm{Ca}_{\mathrm{n}-1} \mathrm{Cu}_{\mathrm{n}} \mathrm{O}_{\mathrm{x}}$ where $\mathrm{A}=\mathrm{Bi}, \mathrm{Tl}$ and $\mathrm{Hg}$ and $\mathrm{M}=\mathrm{Ba}$ or Sr. Among the 
cuprate superconductors, the Bi-based superconductor with general formula $\mathrm{Bi}_{2} \mathrm{Sr}_{2} \mathrm{Ca}_{n}$ ${ }_{1} \mathrm{Cu}_{\mathrm{n}} \mathrm{O}_{2 \mathrm{n}+4+\delta}$ with $\mathrm{n}=1,2$ and 3 is very much considered. Here, $\mathrm{n}=1,2$ and 3 refers to the number of $\mathrm{CuO}_{2}$ layers incorporating and indicates the number of the main phase [1]. The structure of the Bi-based superconductor is a peroveskite structure. The unit cells this superconductor is depended on the number of copper oxide plates along the $\mathrm{c}$ axis. Therefore, the unit cell of this superconductor consists of a chain of pages in form $\left(\mathrm{BiO}_{2}\right)_{2}-\mathrm{Ca}_{\mathrm{n}-1^{-}}$ $\left(\mathrm{CuO}_{2}\right)_{n}$. So the number of pages of the $\mathrm{CuO}_{2}$ is increasing with $\mathrm{n}$ increases [2]. Also, the structure of Bi-based superconductor contains three main phases which are called the Bi-2201 phases $\left(n=1, T_{c} \approx 20 K\right)$, the Bi-2212 phase $\left(n=2, T_{c} \approx 85 K\right)$ and the Bi-2223 phase $\left(\mathrm{n}=3, \mathrm{~T}_{\mathrm{c}} \approx 110 \mathrm{~K}\right)$. Here, we have used the abbreviation Bi-2201, Bi-2212 and Bi-2223 phases for $n=1,2$ and 3, respectively. In these three phases, the Bi-2223 phase is the most attractive, because it has the highest superconducting transition temperature, $\mathrm{T}_{\mathrm{c}}$ about $110 \mathrm{~K}[3,4]$. However, the Bi-2223 single-phase is difficult to obtain due to the coexistence of the $\mathrm{Bi}-2223$ phase with $\mathrm{Bi}-2201, \mathrm{Bi} 2212$ phases, and possible impurities. Formation of Bi-2223 phase and the improvement of the intergranular weak links are influenced by many preparation conditions such as annealing time, annealing temperature, type and quantity of substitution, and operational procedures. Therefore, the major limitations of the Bi-2223 phase superconductor application are the intergranular weak links and the presence of residual secondary phases. Guo et al revealed that the Bi-2201 phase was located mainly between the superconducting grains, preventing the super-current flow [5]. The ac magnetic susceptibility is widely used for the determination and characterization of the intergranular component in high- $\mathrm{T}_{\mathrm{c}}$ superconductors [6]. It has been shown that the dependence of ac magnetic susceptibility on the ac field amplitude (Hac) was determined by the pinning strength parameter [7, 8]. A tremendous effort has been applied to improve the links between the grains and the properties of the Bi-based superconductor, doping them by various 
elements such as $\mathrm{Pb}$ and $\mathrm{Sb}[9,10], \mathrm{Ag}[11,12], \mathrm{Cd}[13,14]$ and $\mathrm{CdO}$ nanoparticles [15]. Mubeen and et al have been studied the substitution of cerium (Ce) on the calcium site of the nominal compositions of $\mathrm{Bi}_{1.6} \mathrm{~Pb}_{0.4} \mathrm{Sr}_{1.6} \mathrm{Ba}_{0.4}\left(\mathrm{Ca}_{1-x} \mathrm{Ce}{ }_{x}\right)_{2} \mathrm{Cu}_{3} \mathrm{O}_{\mathrm{x}}$ ceramic superconductor using the sol-gel method [16]. It seems that the doping of $\mathrm{Ba}$ on the ac magnetic susceptibility properties of the $\mathrm{Bi}_{1.6} \mathrm{~Pb}_{0.4} \mathrm{Sr}_{2-\mathrm{x}} \mathrm{Ba}_{\mathrm{x}} \mathrm{Ca}_{2} \mathrm{Cu}_{3} \mathrm{O}_{\mathrm{y}}$ superconductor synthesized by the sol-gel method has not been properly studied. Solid-state reaction (SSR) method is the oldest, simplest and still most widely used for preparing polycrystalline materials. This method is intrinsically slow because the formation of the superconductivity phase proceeds via diffusion in the solid-state. Multiple grindings and prolonged thermal treatment at high temperature are necessary to obtain a single phase. To achieve better mixing of the initial products, many chemical preparation techniques for precursors have been developed. The most popular and interesting method is carried out by the sol-gel reaction (SGR). It is well known that the SGR method is superior to the SSR in terms of chemical homogeneity and chemical reactivity, which is an important requirement in obtaining optimal superconductor ceramics. In this respect, wet chemical methods have increasingly been used in the fabrication of high temperature ceramic superconductors and compared to solid-state methods, the chemical routes effectively replace the time-consuming and laborious conventional processes, avoiding contamination, loss of stoichiometry and allowing a better control on particle size and morphology. Moreover, the starting solution in the sol-gel method is a homogeneous mixture of the metal ions in the desired stoichiometry ratio. By using the SGR method, not only does the phase purity improves, the grain size also decreases $[17,18]$. Study of superconductivity properties of $\mathrm{Bi}_{1.6} \mathrm{~Pb}_{0.4} \mathrm{Sr}_{2-\mathrm{x}} \mathrm{Ba}_{\mathrm{x}} \mathrm{Ca}_{2} \mathrm{Cu}_{3} \mathrm{O}_{\mathrm{y}}$ superconductor synthesized by the sol-gel method in this research indicated that the optimum annealing time is $\mathrm{t}=48 \mathrm{~h}$, whereas for example in the solid-state reaction (SSR) method, annealing times are $\mathrm{t}=270 \mathrm{~h} \mathrm{[6],t}=170 \mathrm{~h}[2]$ and $\mathrm{t}=96 \mathrm{~h}$ [19]. In this work, we have systematically studied the 
effects of $\mathrm{Ba}$ substitution for $\mathrm{Sr}$ in $\mathrm{Bi}_{1.6} \mathrm{~Pb}_{0.4} \mathrm{Sr}_{2-\mathrm{x}} \mathrm{Ba}_{\mathrm{x}} \mathrm{Ca}_{2} \mathrm{Cu}_{3} \mathrm{O}_{\mathrm{y}}$ superconductor with $\mathrm{x}=0.0$, $0.05,0.1,0.15,0.2,0.25$, and 0.3 by the sol-gel method and the ac magnetic susceptibility and structural properties of the samples were studied.

\section{Material and methods}

Samples of $\mathrm{Bi}_{1.6} \mathrm{~Pb}_{0.4} \mathrm{Sr}_{2-\mathrm{x}} \mathrm{Ba}_{\mathrm{x}} \mathrm{Ca}_{2} \mathrm{Cu}_{3} \mathrm{O}_{\mathrm{y}}$ with $\mathrm{x}=0.0,0.05,0.1,0.15,0.2,0.25$, and 0.3 , at respective annealing times of $32,48,64 \mathrm{~h}$ were prepared using a sol-gel method. In order to prepare $\mathrm{Bi}_{1.6} \mathrm{~Pb}_{0.4} \mathrm{Sr}_{2-\mathrm{x}} \mathrm{Ba}_{\mathrm{x}} \mathrm{Ca}_{2} \mathrm{Cu}_{3} \mathrm{O}_{\mathrm{y}}$ using the sol-gel method, the high-purity raw materials of $\mathrm{Bi}\left(\mathrm{NO}_{3}\right)_{2} . \quad 5 \mathrm{H}_{2} \mathrm{O}, \quad \mathrm{Pb} \quad\left(\mathrm{CH}_{3} \mathrm{COO}\right)_{2} . \quad 3 \mathrm{H}_{2} \mathrm{O}, \quad \mathrm{Sr}\left(\mathrm{NO}_{3}\right)_{2} . \quad 0.5 \mathrm{H}_{2} \mathrm{O}, \quad \mathrm{Ba}\left(\mathrm{NO}_{3}\right)_{2} \cdot 0.5 \mathrm{H}_{2} \mathrm{O}, \quad \mathrm{Ca}$ $\left(\mathrm{CH}_{3} \mathrm{COO}\right)_{2}$ 2. $\mathrm{H}_{2} \mathrm{O}, \mathrm{Cu}\left(\mathrm{CH}_{3} \mathrm{COO}\right)_{2} . \mathrm{H}_{2} \mathrm{O}$ and acetic acid were used as precursors. The required quantities of reagents were weighed $\left(\Delta \mathrm{m}=10^{-4} \mathrm{mg}\right)$. First, the $\mathrm{Bi}\left(\mathrm{NO}_{3}\right)_{2} \cdot 0.5 \mathrm{H}_{2} \mathrm{O}$ in acetic acid (100 \%) was solved. Afterward, $\mathrm{Sr}\left(\mathrm{NO}_{3}\right)_{2} .0 .5 \mathrm{H}_{2} \mathrm{O}, \quad \mathrm{Ba}\left(\mathrm{NO}_{3}\right) .0 .5 \mathrm{H}_{2} \mathrm{O}$, $\mathrm{Ca}\left(\mathrm{CH}_{3} \mathrm{COO}\right)_{2} \cdot \mathrm{H}_{2} \mathrm{O}, \mathrm{Cu}\left(\mathrm{CH}_{3} \mathrm{COO}\right)_{2} . \mathrm{H}_{2} \mathrm{O}$, and ammonium hydroxide $(25 \%)$ were dissolved and this solution was added to the initial solution. Also, $\mathrm{Pb}\left(\mathrm{CH}_{3} \mathrm{COO}\right)_{2} . \mathrm{H}_{2} \mathrm{O}$ was separately dissolved in deionized water and added to the previous mixture. In order to the form of a homogenized solution; the entire dissolved mixture was stirred with $3 \mathrm{~h}$ by a magnetic stirrer. To prevent deposition of the solution, the $\mathrm{pH}$ value of the solution was adjusted at 5.5 with ammonia hydroxide $(25 \%)$. A concentrated gel was formed by heating the solution at $70{ }^{\circ} \mathrm{C}$. The gel was placed in the electric oven at $110^{\circ} \mathrm{C}$ until it turned into a dry-gel. By increasing the temperature, ammonium hydroxide and nitrate groups were released and as a result, the whole citrate complex was consumed. In order to prevent the growth of additional phases during the process, the dry-gel was annealed at $820{ }^{\circ} \mathrm{C}$ for $15 \mathrm{~h}$ in the air. The powders were taken out from the furnace, re-ground, and pressed (at $447 \mathrm{M} \mathrm{Pa}$ ) into the shape of bars. The bars were sintered in the air at $845^{\circ} \mathrm{C}$ for annealing times of 32,48 , and $64 \mathrm{~h}$. The XRD patterns were performed ( $\Delta \theta=1 \times 10^{-3}$ degree) using a Philips X-ray diffractometer Model PW1840 to investigate the structural properties. The ac magnetic susceptibility 
measurements were performed $\left(\Delta \chi=1 \times 10^{-4}\right)$ using a Lake Shore ac susceptometer, Model 7000.

\section{Results and discussions}

Fig. 1 shows the thermo-gravimetric analysis (TGA) and differential thermal analysis (DTA) curve of the dry- gel precursor of $\mathrm{Bi}_{1.6} \mathrm{~Pb}_{0.4} \mathrm{Sr}_{2-\mathrm{x}} \mathrm{Ba}_{\mathrm{x}} \mathrm{Ca}_{2} \mathrm{Cu}_{3} \mathrm{O}_{\mathrm{y}}$ superconductor with $\mathrm{x}=0.0$ by a solgel method. During heat treatment of the samples, several processes such as dehydration, decomposition, and sintering take place. The TGA curve reveals six distinct steps of weight loss. The first step weight loss within the temperature range from $96{ }^{\circ} \mathrm{C}$ to about $256{ }^{\circ} \mathrm{C}$ is associated with the elimination of water and evaporation of volatile organic compounds remaining in the sample. The second step weight loss from $256{ }^{\circ} \mathrm{C}$ to $384{ }^{\circ} \mathrm{C}$ is mainly caused the burning of nitrates and organic compounds in the sample. The third step weight loss from $384{ }^{\circ} \mathrm{C}$ to about $565{ }^{\circ} \mathrm{C}$ could be due to the elimination of all acetates in the sample. The fourth step weight loss from $565{ }^{\circ} \mathrm{C}$ to $631{ }^{\circ} \mathrm{C}$ has a phase which is due to the formation beginning of Bi-2201 phase. The fifth step weight loss from $631{ }^{\circ} \mathrm{C}$ to $858{ }^{\circ} \mathrm{C}$ is related to the formation of $\mathrm{Bi}_{1.6} \mathrm{~Pb}_{0.4} \mathrm{Sr}_{2-x} \mathrm{Ba}_{x} \mathrm{Ca}_{2} \mathrm{Cu}_{3} \mathrm{O}_{\mathrm{y}}$ superconductor. In the sixth step from $858{ }^{\circ} \mathrm{C}$ to about $1201^{\circ} \mathrm{C}$, very low weight loss has been observed, which is due to removal of elements in the $\mathrm{Bi}_{1.6} \mathrm{~Pb}_{0.4} \mathrm{Sr}_{2-\mathrm{x}} \mathrm{Ba}_{\mathrm{x}} \mathrm{Ca}_{2} \mathrm{Cu}_{3} \mathrm{O}_{\mathrm{y}}$ composition and the gradual formation of additional phases. From Fig. 1 we see that the DTA curve has two endothermic peaks around $577{ }^{\circ} \mathrm{C}$ and around $1050{ }^{\circ} \mathrm{C}$ and two exothermic peaks around $240{ }^{\circ} \mathrm{C}$ and $345^{\circ} \mathrm{C}$. The endothermic peak at $577{ }^{\circ} \mathrm{C}$ is due to the formation beginning of $\mathrm{Bi}-2201$ phases. The endothermic peak at $1050{ }^{\circ} \mathrm{C}$ is attributed to the decomposition of elements in the sample and the gradual formation of additional phases. The exothermic peak at $240{ }^{\circ} \mathrm{C}$ can be due to burning and decomposition of nitrates and other organic compounds. The exothermic peak at $345^{\circ} \mathrm{C}$ can be due to the elimination of all acetates in the sample [20, 21].

The XRD patterns of $\mathrm{Bi}_{1.6} \mathrm{~Pb}_{0.4} \mathrm{Sr}_{2-\mathrm{x}} \mathrm{Ba}_{\mathrm{x}} \mathrm{Ca}_{2} \mathrm{Cu}_{3} \mathrm{O}_{\mathrm{y}}$ annealed at $845{ }^{\circ} \mathrm{C}$ with annealing times of 32 , 48, and $64 \mathrm{~h}$ are shown in Fig. 2. Based on our XRD measurements, we observed that the substitution of $\mathrm{Ba}$ for $\mathrm{Sr}$ in the sample with an amount of $\mathrm{x}=0.2$ cause an increase in the 
fraction the $\mathrm{Bi}-2223$ phase, which this increase probably is related to the creation of a liquid phase in the sample. With increasing of $x>0.2$, the volume fraction of the Bi-2223 phase decreases. The XRD patterns of samples with $\mathrm{x}=0.2$ and annealing times of 32,48 , and 64 show that with increased annealing up to $48 \mathrm{~h}$, a fraction of the Bi-2223 phase increases. The volume fraction of the phases can be estimated with relation 1 [22]. The volume fractions of the phases for all samples are given in the Tables 1-3. As shown in the Tables 1-3, the maximum volume fraction of the $\mathrm{Bi}-2223$ phase is obtained for the sample with $\mathrm{x}=0.2$ and an annealing time of $48 \mathrm{~h}$. The lattice parameters of the samples with Ba contents of $\mathrm{x}=0.0$, $0.1,0.2$, and 0.25 at an annealing time of $48 \mathrm{~h}$ and also samples with annealing times of $\mathrm{t}=$ 32, 48, and 64 with $\mathrm{x}=0.2$ were calculated and are given in the Tables 4 and 5 . The results of Tables 4 and 5 reveal that the volume of the unit cell and lattice parameter of the doped sample increase compared to those of the undoped samples, which indicate substitution of $\mathrm{Ba}$ for $\mathrm{Sr}$.

$$
\begin{array}{ll}
B i-2223(\%)=\frac{\sum I(B i-2223)}{A} \times 100 & B i-2201(\%) \approx \frac{\sum I[B i-2201]}{A} \times 100 \\
B i-2212(\%) \approx \frac{\sum I[B i-2212]}{A} \times 100 & B a B i O_{3}(\%) \approx \frac{\sum I\left[B a B i O_{3}\right]}{A} \times 100 \\
P b O(\%) \approx \frac{\sum I(P b O)}{A} \times 100 & \\
A \equiv \sum I[B i-2223]+\sum I[B i-2212]+\sum I[B i-2201]+\sum I(P b O)+\sum I\left[\mathrm{BaBiO}_{3}\right]
\end{array}
$$

Figure 3- (a), (b) and (c) show SEM micrographs for the samples with amounts of $\mathrm{Ba}$ of $\mathrm{x}=0.0,0.2$ and 0.3 with annealing time of $48 \mathrm{~h}$. It seems that with increasing the amount of $\mathrm{Ba}(\mathrm{x}=0.3)$ leads to the formation of a liquid phase that act as an insulating layer around the superconductor grain. Also, for the amount of $x=0.0$ leads to the formation of more pores. These pores act as a weak links between the grains. These pores and insulators layers destroy grains connectivity and disrupt current flow. It can be seen from Figure 3- (b) 
which weak links between the grains in the sample with $\mathrm{x}=0.2$ are better than those that of the other doped and undoped samples.

Figure 4 a shows the temperature dependence of the real $\left(\chi^{\prime}\right)$ and imaginary $\left(\chi^{\prime \prime}\right)$ parts of ac magnetic susceptibility for samples with Ba contents of $\mathrm{x}=0.0,0.1,0.2,0.25$ and 0.3 and an annealing time of $48 \mathrm{~h}$ in the ac field of $0.0628 \mathrm{Oe}$ with a frequency of $333 \mathrm{~Hz}$ which is applied parallel to the long dimension of the samples. In particular, the imaginary component $\left(\chi^{\prime \prime}\right)$ of the ac magnetic susceptibility has been widely used to probe the nature of the weak links in polycrystalline superconductors. The real part of the ac magnetic susceptibility $\left(\chi^{\prime}\right)$ in the polycrystalline samples shows two drops as the temperature is lowered below the onset of the diamagnetic transition and correspondingly the derivative of the $\chi^{\prime}(\mathrm{T})$ displays two peaks. The first sharp drop at the critical temperature is due to the transition within the grains and the second gradual change is due to the occurrence of the superconducting coupling between the grains. The imaginary part $\left(\chi^{\prime \prime}\right)$ shows a peak which is a measure of the dissipation in the sample. When the peak of $\left(\chi^{\prime \prime}\right)$ shifts to lower temperatures and broadens, the intergranular coupling between the grains decreases and destroy the superconductivity of the samples $(\mathrm{x}=0.0,0.3)[23,24]$. According to the data given in this Figure, it can be concluded that the onset critical temperature of the samples is about $108 \mathrm{~K}$. Although the intragranular critical temperature of the samples is almost the same, but the intergranular critical temperature it occurs at different temperatures. It can be seen from the curves that the intergranular coupling between the grains of the samples is increased with increased $\mathrm{Ba}$ content up to $\mathrm{x}=0.2$. Therefore, the intergranular transition temperature and coupling between the grains of the sample with $\mathrm{x}=0.2$ occur at a higher temperature than that of the undoped sample $(\mathrm{x}=0.0)$. For samples with $\mathrm{x}>0.2$, the superconductivity properties such as the ac magnetic susceptibility, intergranular transition temperature, and coupling between grains were decreased $(\mathrm{x}=0.3)$. Therefore, it can be concluded that the diamagnetic and 
conductivity properties and weak links between the grains in the sample with $x=0.2$ are better than those that of the other doped and undoped samples [25, 26].

Figure $4 \mathrm{~b}$ shows the results of the ac magnetic susceptibility measurements of the sample with $\mathrm{x}=0.02$ and annealing times of 32,48 , and $64 \mathrm{~h}$ for an ac magnetic field of $0.0628 \mathrm{Oe}$ with a frequency of $333 \mathrm{~Hz}$. From Figure 4b, it can be seen that with increasing annealing time up to $48 \mathrm{~h}$, the peak of $\chi^{a s}$ shifts to higher temperature. These results indicate that the intergranular coupling between grains have been increased up to $48 \mathrm{~h}$. The $\chi^{\leftarrow}$ curves show that two phases are present in each case and these shifts towards the right of the temperature scale after each annealing time. The diamagnetic transition in $\chi^{s}(\mathrm{~T})$ occurs sharply in the first phase and this diamagnetic transition increases with an increase in annealing times. The slow transition in the case of the second phase is reflected from the granular structure of the material with weak links in the intergranular regions. The first phase is referred to as the Bi-2223 phase for all of the annealing times. The second drop in $\chi^{s}(\mathrm{~T})$ for 32 and $64 \mathrm{~h}$ annealing times is observed while the Bi-2223 phase in this region has fallen. For $48 \mathrm{~h}$ annealing time, the second phase was far from the expected, so it can be safely stated that this second drop in $\chi^{5}(\mathrm{~T})$ is due to intergranular coupling transition. The magnitude of the diamagnetic increased with increasing annealing time up to $48 \mathrm{~h}$, which shows an increase in a superconducting fraction; however, an actual estimate of the superconducting fraction is not possible. The sample with $64 \mathrm{~h}$ annealing time has the weakest magnitude of the diamagnetic among all the samples. This implies that step-wise annealing time is more favorable for magnetic properties of the superconductor [27, 28, 29].

Figure $4 \mathrm{c}$ shows the results of ac magnetic susceptibility measurements for the sample with $\mathrm{x}=0.2$ and an annealing time of $48 \mathrm{~h}$ for various ac fields with a frequency of $333 \mathrm{~Hz} . \mathrm{AC}$ losses in the type II superconductors arise from viscous flux flow motion and hysterics due to pinning of flux vortices [30]. Many researchers have observed that the complex ac magnetic 
susceptibility of high- $T_{c}$ superconductors is strongly dependent on the ac magnetic field amplitude $\left(\mathrm{H}_{\mathrm{ac}}\right)$. It has been shown that the dependence of ac magnetic susceptibility on ac field amplitude $\left(\mathrm{H}_{\mathrm{ac}}\right)$ is determined by the pinning strength parameter. It is clear from Figure $4 \mathrm{c}$ that as the field increases the peak of $\chi^{\prime \prime}$ shifts to lower temperatures and broadens. Therefore, with increasing ac magnetic fields, superconductivity of the samples is quenched. The peak temperatures $\left(T_{p}\right)$ for $x=0.2$ with different ac magnetic fields are shown in Fig. 5 . It can be seen in the Fig. 5 that with increasing ac magnetic field amplitude, peak temperature $\left(T_{p}\right)$ shifts to lower temperature. The intergranular peak shifts to lower temperature as the ac field amplitude increases for the samples studied as reported previously [31, 32, 33]. According to these data, it is clear that the penetration of ac field and the shielding current into the center of the sample take place below the superconducting transition temperature of the sample in the presence of the ac magnetic fields. From Fig. 5 one can see that for the fields above 5.026 Oe the superconductivity properties of the drop in comparison with others. Figure 6 shows the results of ac magnetic susceptibility measurements for the sample with $\mathrm{Ba}$ content of $x=0.2$ and an annealing time of $48 \mathrm{~h}$ with different frequencies of $\mathrm{f}=33,333$, 666, and $1000 \mathrm{H}_{\mathrm{z}}$ for a field of 0.0628 Oe. Many researchers such as Muller have observed that the complex ac magnetic susceptibility of high- $\mathrm{T}_{\mathrm{c}}$ superconductors is weakly dependent on the frequency and strongly on the amplitude of ac magnetic field.

From Figure $7 \mathrm{a}$, it can be seen that with increasing frequency, the peak temperature $\left(T_{\mathrm{p}}\right)$ of the imaginary part $\left(\chi^{\prime \prime}\right)$ slightly goes high temperature. Also, it can be seen that with increasing the amplitude of ac magnetic field the peak temperature $\left(\mathrm{T}_{\mathrm{p}}\right)$ of the imaginary part $\left(\chi^{\prime \prime}\right)$ goes high temperature (Figure 7b) [34].

In order to reach full flux penetration, the effective intergranular pinning force density must be weakened. Since the pinning force density weakens with increasing temperature, the peak 
temperature $\left(T_{p}\right)$ must increase with increasing frequency. The maximum $\chi^{\prime \prime}(T)$ is at a frequency given by the following relationship:

$$
f=f_{0} \exp \left(-\frac{U}{K_{B} T}\right)
$$

In the above equation, $f_{0}$ is an attempt frequency and $U$ is the activation energy for flux creep.

Fig. 8 shows a plot of $\ln \mathrm{f}$ vs. $1 / \mathrm{T}_{\mathrm{p}}$ for the sample with $\mathrm{x}=0.2, \mathrm{H}_{\mathrm{ac}}=0.0628 \mathrm{Oe}$, and an annealing time of $48 \mathrm{~h}$. The value of $U / K_{B}$ can be obtained from the slope plot of Fig. 8, where activation energy for this sample is $\mathrm{U}=29.44 \times 10^{-20}(\mathrm{~J})[35,36]$.

\section{Conclusions}

The role of the sol-gel method and doping of $\mathrm{Ba}$ in the drastic reduction of the annealing time and the improvement of the coupling between grains of $\mathrm{Bi}_{1.6} \mathrm{~Pb}_{0.4} \quad \mathrm{Sr}_{2-\mathrm{x}} \mathrm{Ba}_{\mathrm{x}} \mathrm{Ca}_{2} \mathrm{Cu}_{3} \mathrm{O}_{\mathrm{y}}$ superconductor was investigated. For example, the study of superconductivity properties of $\mathrm{Bi}_{1.6} \mathrm{~Pb}_{0.4} \mathrm{Sr}_{2-\mathrm{x}} \mathrm{Ba}_{\mathrm{x}} \mathrm{Ca}_{2} \mathrm{Cu}_{3} \mathrm{O}_{\mathrm{y}}$ superconductor synthesized by the sol-gel method in this research indicated that the optimum annealing time is $\mathrm{t}=48 \mathrm{~h}$, whereas in other fabrication methods such as the solid-state reaction (SSR) method, annealing times are $\mathrm{t}=270 \mathrm{~h}$ or $190 \mathrm{~h}$. From $\mathrm{XRD}$ results, we can conclude that the sample doped with $\mathrm{Ba}$ having $\mathrm{x}=0.2$ at annealing time of $48 \mathrm{~h}$, showing an increased in the percentage of the Bi-2223 phase. Also, the lattice parameter and volume of the unit cell of doped samples were increased with respect to undoped samples, which shows that Ba has been substituted by Sr. It can be seen from SEM images which weak links between the grains in the sample with $\mathrm{x}=0.2$ are better than those that of the other doped and undoped samples. The results of ac magnetic susceptibility measurements for the samples show that the diamagnetic fraction and coupling between the grains in the sample with $\mathrm{Ba}$ content of $\mathrm{x}=0.2$ and an annealing time of $48 \mathrm{~h}$ is higher than 
those in the other samples. The results of ac magnetic susceptibility show that with increasing ac field, the peak of $\chi^{\prime \prime}$ shift lower temperature and consequently coupling between the grains decreases. Although, with increasing frequency, there is no significant change in the real part ac magnetic susceptibility, but the imaginary part shows a slight shift to higher temperature. In this regard, the frequency dependence of ac magnetic susceptibility can be attributed to intergranular flux creep or magnetic relaxation.

\section{Acknowledgments}

The authors are grateful to Shahid ChamranUniversity of Ahvaz for providing us with financial support for this project.

\section{Financial}

This study was funded by Shahid ChamranUniversity of Ahvaz (grant number: SCU.SP98.130)

\section{Conflict of interest statement:}

I am Seyed Ebrahim Mousavi Ghahfarokhi as the corresponding author "The role solgel method and doping $\mathrm{Ba}$ in the drastic reduction of the annealing time and the improvement of the coupling between grains of $\mathrm{Bi}_{1.6} \mathrm{~Pb}_{0.4} \mathrm{Sr}_{2}$ ${ }_{x} \mathrm{Ba}_{x} \mathrm{Ca}_{2} \mathrm{Cu}_{3} \mathrm{O}_{\mathrm{y}}$ superconductor “, explicitly announce that with the submission of this manuscript, I would like to undertake that the above mentioned manuscript has not been published elsewhere, accepted for publication elsewhere or under editorial review for publication elsewhere; and that my Institute's (Shahid Chamran University of Ahvaz) representative is fully aware of this submission. As well as, the selection of suggested referees only is due to a lot of the researches that have been done in this field.

Sincerely yours,

Seyed Ebrahim Mousavi Ghahfarokhi 


\section{References}

[1] Mamalis A G, Melonakos D E, szalay A, pantazopoulos G, 2000 INC. New Holland Avenue 851.

[2] Salamati H, Kameli P and Morshedioo T, 2011 J. Supercond. Nov. Magn. 241267.

[3] Nishi Y, Kita Y, and Tanioka K, 1990 J. Mate. Sci. 255105.

[4] Sarkar K A, Maartense I, Peterson T L and Kumar B, 1989 J. Appl. Phys. 66, 3717.

[5] Guo Y C, Horvat J, Liu H K and Dou S X, 1998 Physica C 30038.

[6] Zargar Shoushtari M and Mousavi Ghahfarokhi S E, 2011 J. Supercond. Nov. Magn. 241505.

[7] Mollah S, 2002 Mater. Lett. 52159.

[8] Rhee C K, Kim C J, Lee H G, Kuk I H, Lee J M, Chang I S and et al., 1989 Jpn. J. Appl. Phys. 28 L1137.

[9] Dou S X, Liu H K, Bourdillon A J, Kviz M, Tan N X and C C, 1989 Phys. Rev. B 40 5266.

[10] Sarkar B, Reddy Y S and Sharma R G, 1994 Physica C 21926.

[11] A Oota, Ogawa K, Maeda J and Shibata K, 1995 Appl. Phys. Lett. 67854.

[12] Zargar Shoushtari M, Bahrami A and Farbod M, 2006 Phys. Stat. Sol. (c) 32994.

[13] Kandyel E and Elsabawy K M., 2006 Physcia C434 141.

[14] Sasakura H, Tagay K, Akagi Y, Oka T, Tsukui S, Adachi M and et al, $2001 \mathrm{~J}$. Superconductivity, 14581.

[15] Mousavi Ghahfarokhi S E, Hoseenzadeh N, Zargar Shoushtari M, $2014 J$. Supercond. Nov. Magn. 272217.

[16] Mubeen M, Anis-ur-Rehman M, 2013 J. Supercond. Nov. Magn. 261123.

[17] Yeoh L M and Ahmad M, 2008 J. Non-Crystalline Solids 3544012. 
[18] Rubešová K, Jakeš V, Hlásek T, Vašek P and Matějka P, 2012 J. Physics and Chemistry of Solids $\mathbf{7 3} 448$.

[19] Celebi S, Karaca I, Ozturk A, Nezir S, 1998. J Alloys and compounds 268256.

[20] Katsuhisa T, Akiyoshi N, and Kanichi K, 1990 J. Mate. Sci.25 3551.

[21] Liu R S, Wang W N, Chang C T and Wu Japanese P T, 1989 J.

Appl. Phys. 282155.

[22] Mousavi Ghahfarokhi S E, and Zargar Shoushtari M, 2014 J. Supercond. Nov. Magn. 271153.

[23] Sedky A, and Youssif, 2001 M, J. Magn. Magn. Mater. 23722.

[24] Karaca I, Celebi S, Varilci, A and Malik A I, 2003 Supercond. Sci. Technol. 16100.

[25] Lee J H, Kim Y C, Kim B J and Jeong D Y, 2001 Physica C350 83.

[26] Yazici D, Erdem M and Ozcelik B, 2012 J. Supercond. Nov. Magn. 25725.

[27] Jiang J, Cai X Y, Chandler J G, Patnaike S, Polyanskii A A, Yuan Y and et al, 2003 IEEE Trans. Appl. Supercond. 133018.

[28] Ekin J W, Larson T M, Hermann A M, Sheng Z Z, Togano K and H Kumakura, 1989 Physica C160 489.

[29] Paasi J, Lahtinen M, Eriksson J T and Polák M, 1996 Physica C259 1.

[30] Celebi S, Aksu I E, Gencer A, 1998 Physica C 309131.

[31] Makarova M V, Kazin P E, Tretyakov Y D, Jansen M, Reissner M and Steiner W 2005 Physica C419 61.

[32] Lang W, Jodlbauer H, Markowitsch, Markowitsch W, Schaffarich P, and Kasmany H, 1989 Physica C 162-167 1639.

[33] Russel G J, Tayler K N R, Matthews D N, Bailey A and Vaile R A, 1989 Physica C162-164 327. 
[34] Müller K H, 1990 Physica C168 585.

[35] Nikolo M and Goldfarb R B, 1989 Phys. Rev. B39 6615.

[36] Anderson P W, 1962 Phys. Rev. Lett. 9309. 


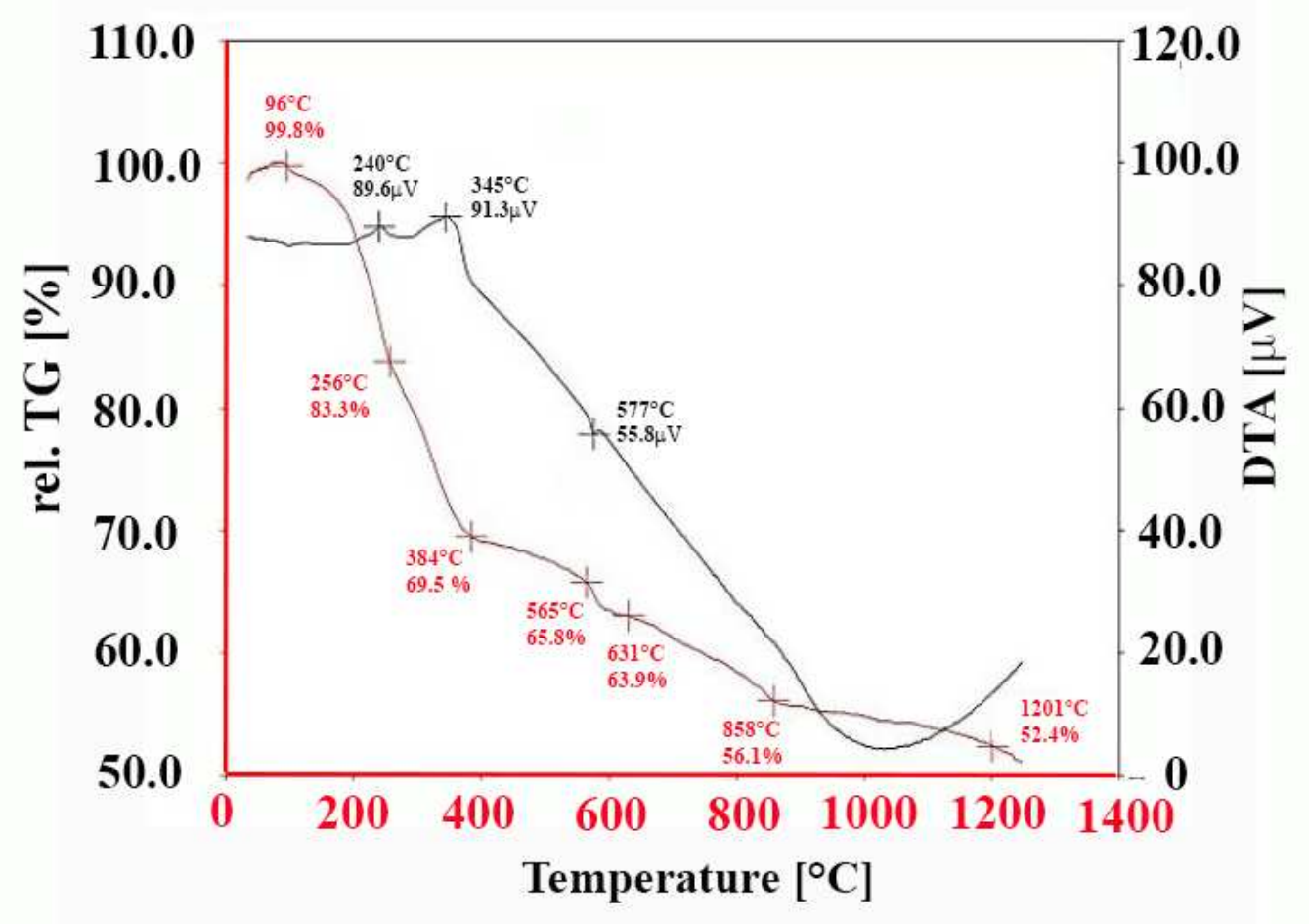

Figure 1: TGA and TDA curves for the gel dried at $110^{\circ} \mathrm{C}$.

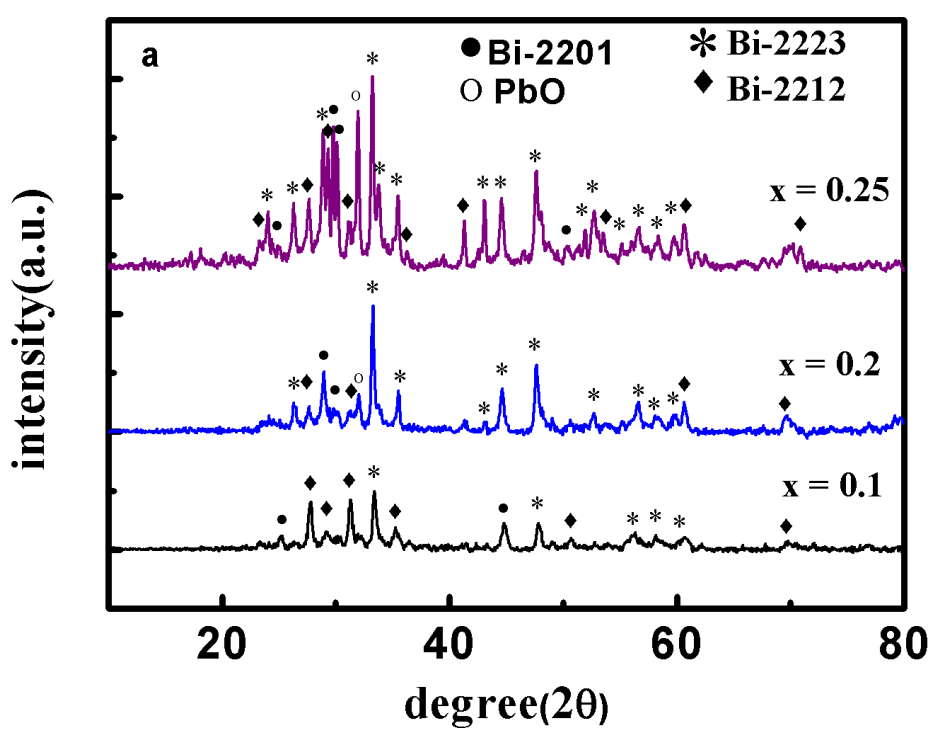

Fig. 2a: XRD patterns of samples with Ba contents of $x=0.1,0.2,0.25$, and an annealing time of $32 \mathrm{~h}$. 


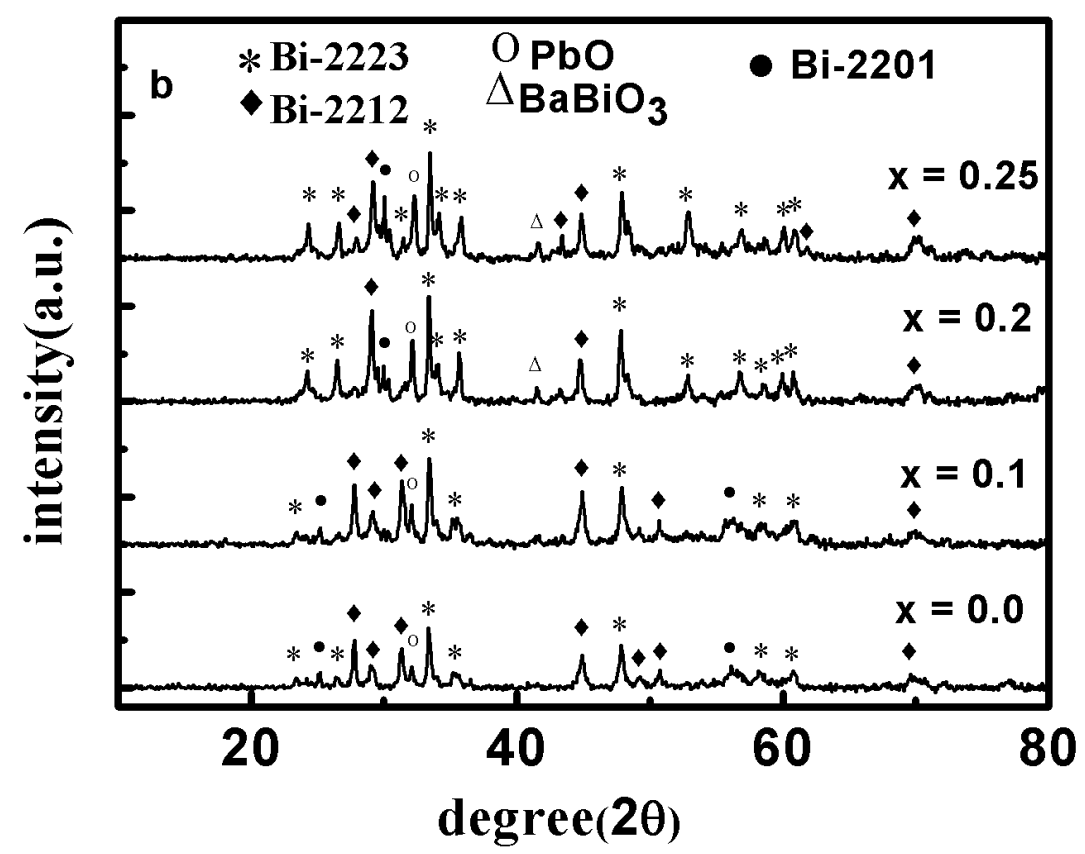

Fig. 2b: XRD patterns of samples with Ba contents of $x=0.0,0.1,0.2,0.25$, and an annealing time of $48 \mathrm{~h}$.

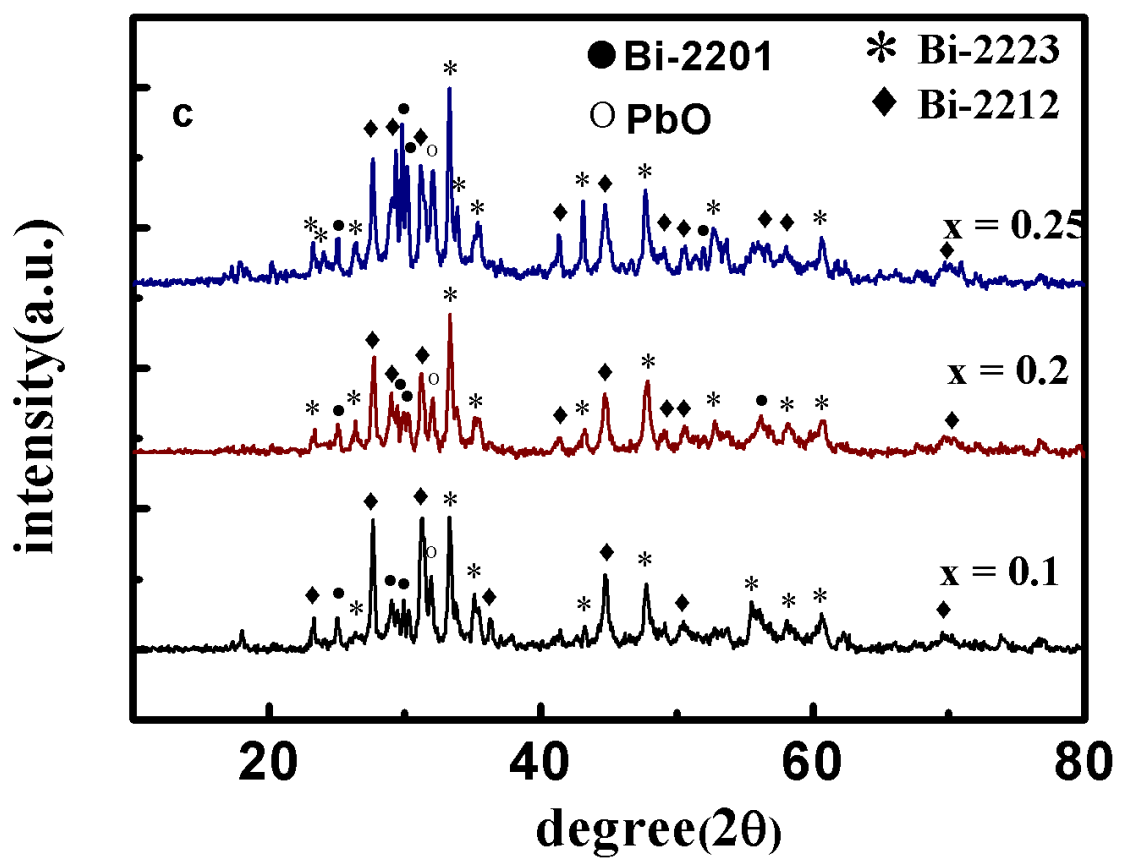

Fig. 2c: XRD patterns of samples with $B$ a contents of $x=0.1,0.2,0.25$, and an annealing time of $64 \mathrm{~h}$ 

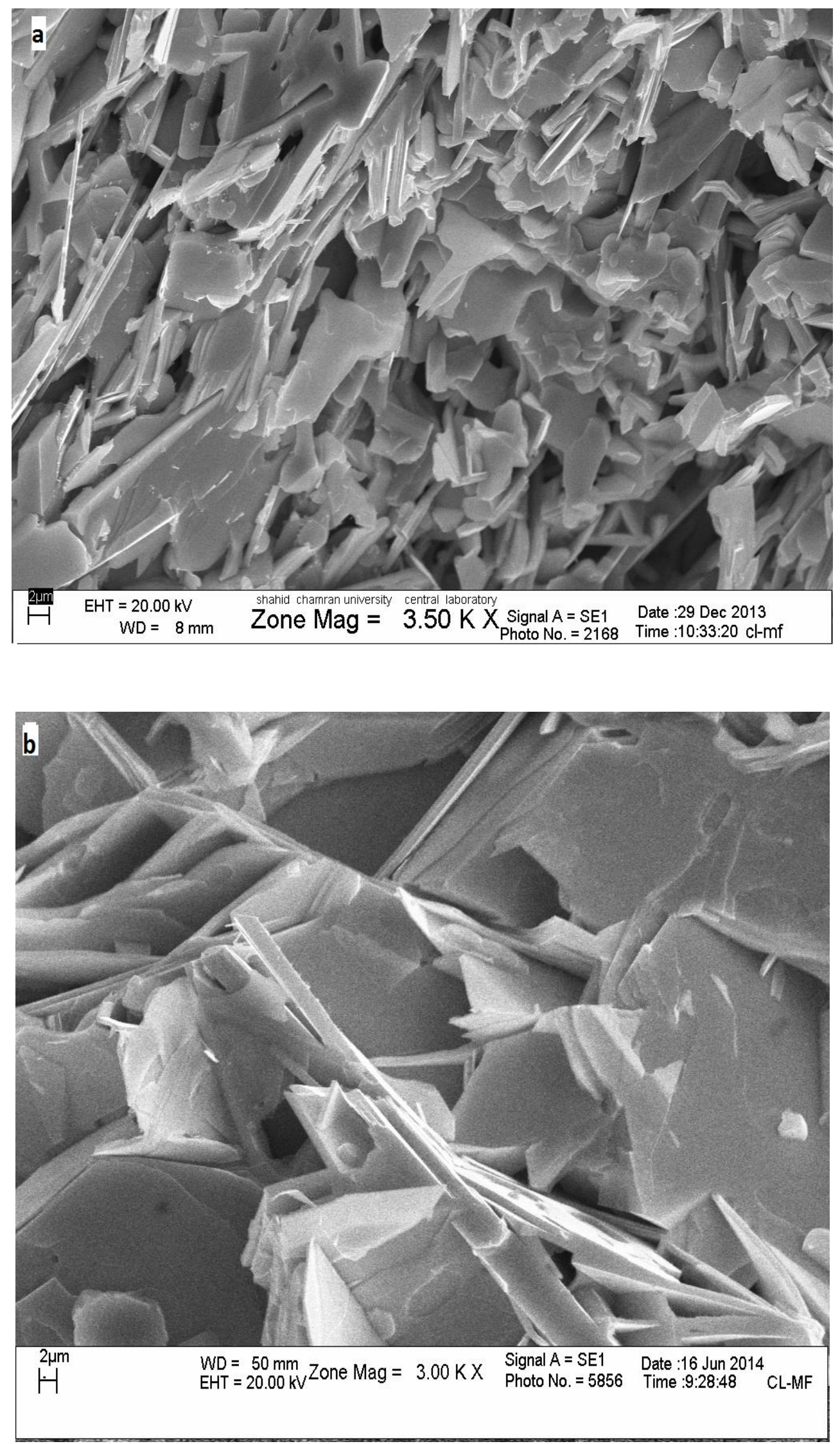


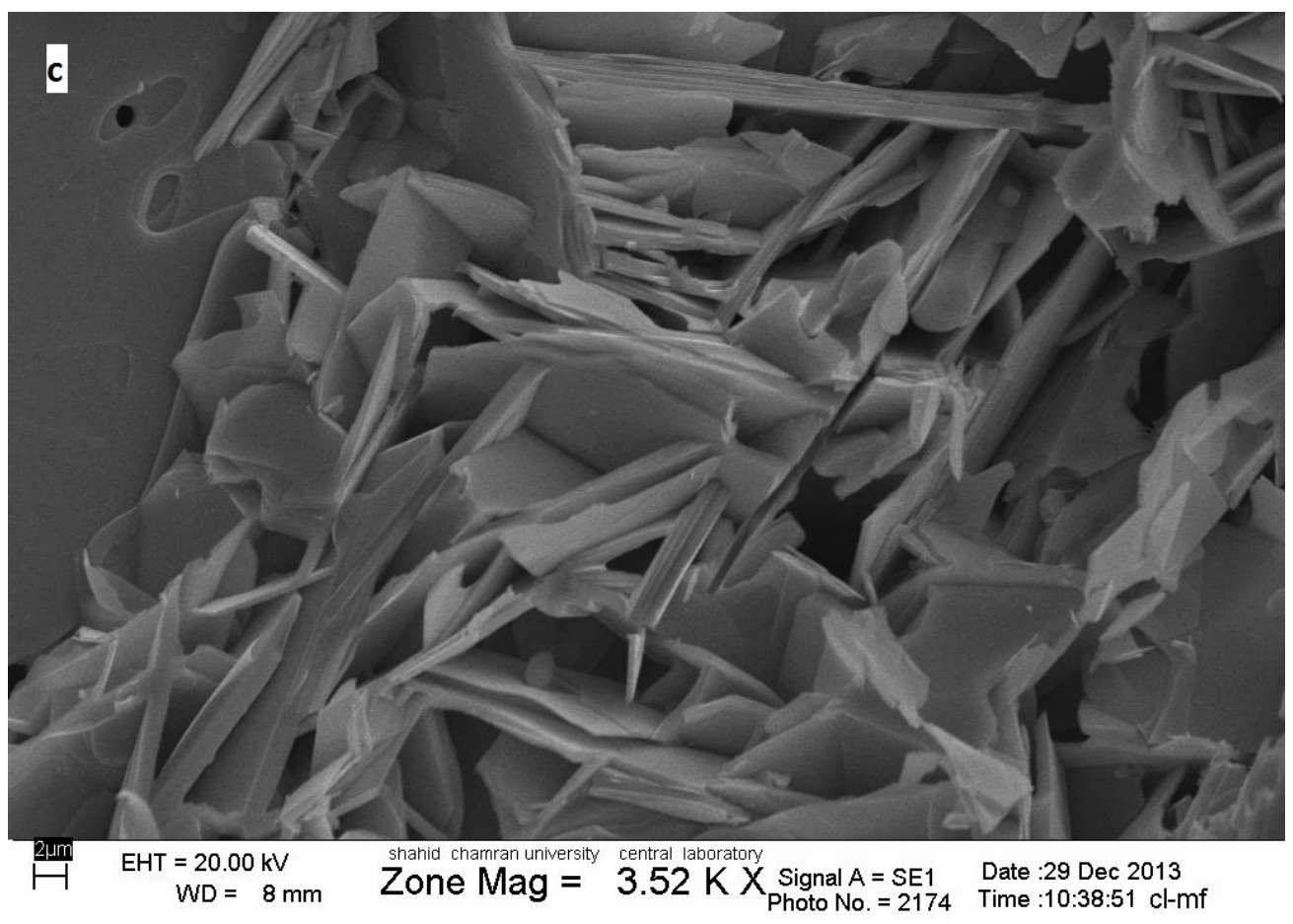

Fig. 3: The SEM micrographs of samples with different amounts of Ba: a) 0.0, b) 0. 2, and c) 0.3 with annealing time of $48 \mathrm{~h}$.

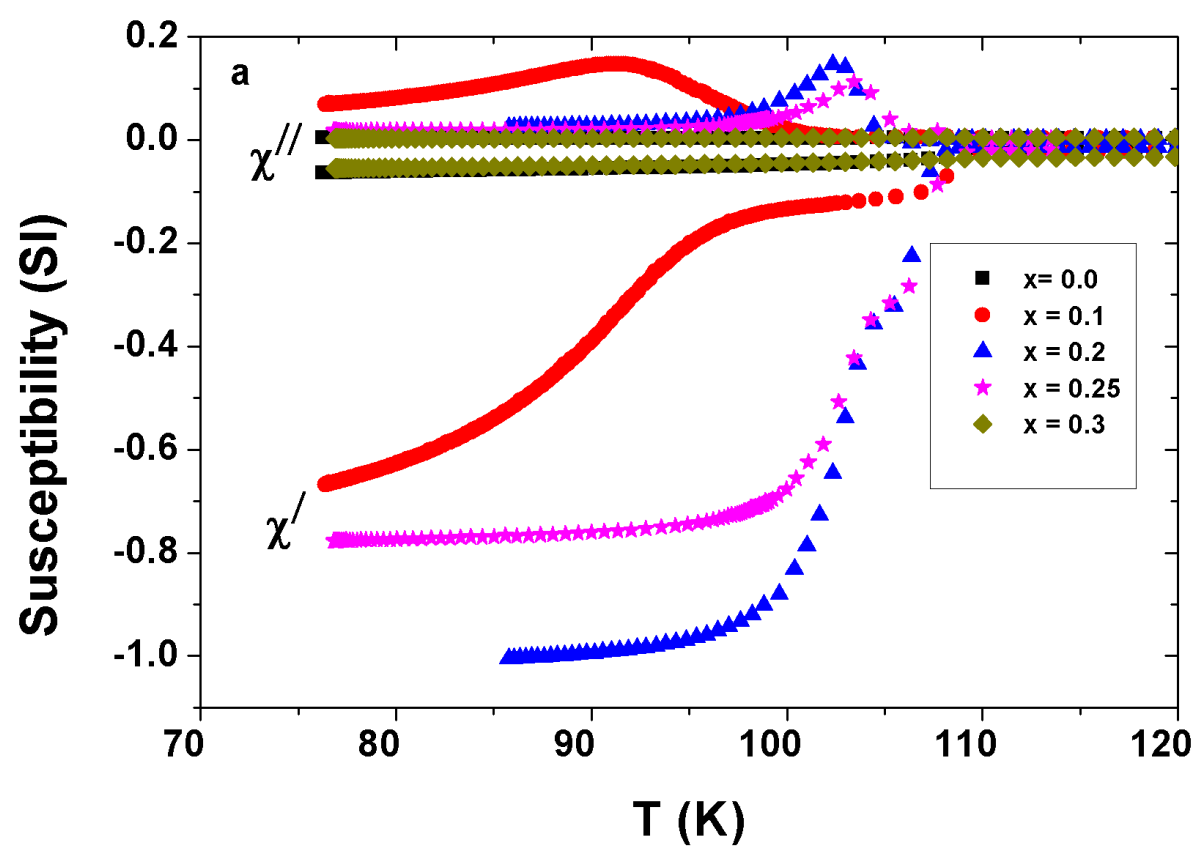

Fig. 4a: Temperature dependence of the magnetic susceptibility for samples with different Ba contents, $\mathrm{H}_{\mathrm{ac}}=0.0628 \mathrm{Oe}, \mathrm{f}=333 \mathrm{H}_{\mathrm{z}}$, and an annealing tame of $48 \mathrm{~h}$. 


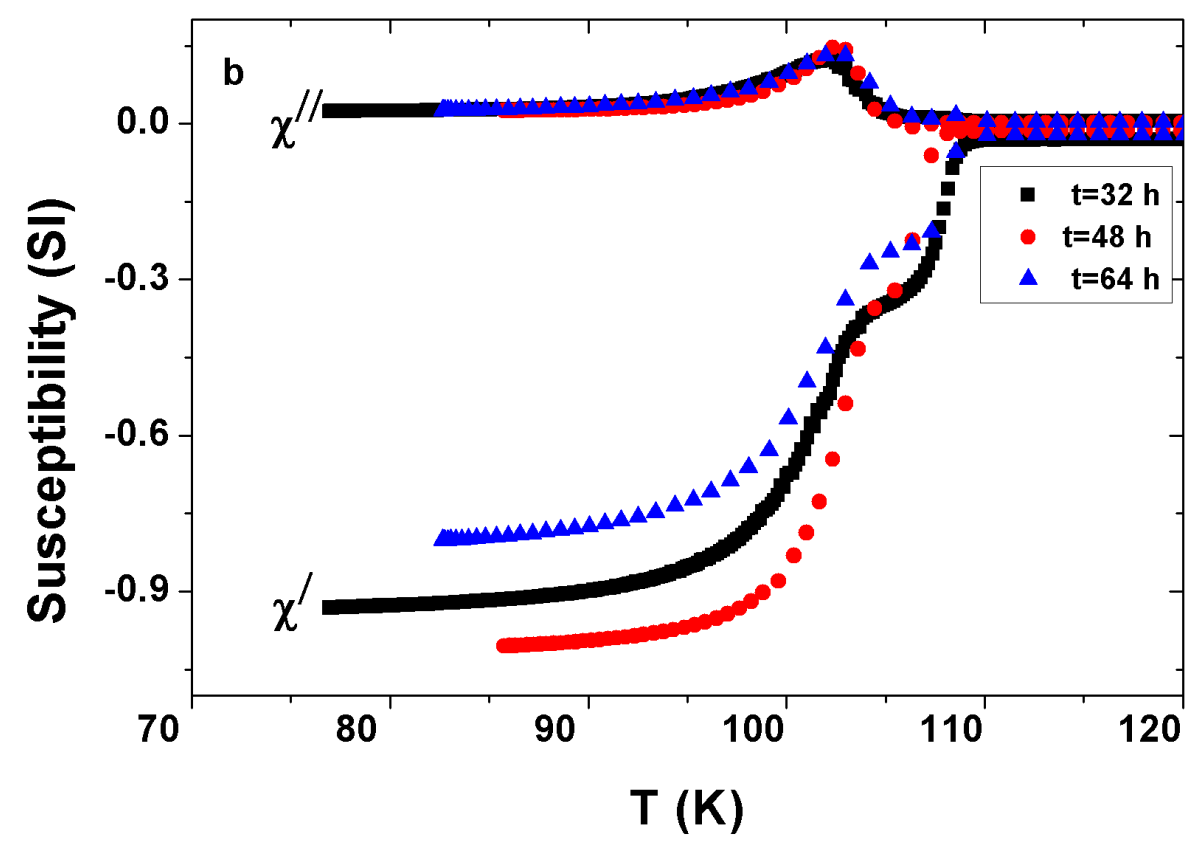

Fig. 4b: Temperature dependence of the magnetic susceptibility under different annealing times, $\mathrm{H}_{\mathrm{ac}}=0.0628 \mathrm{Oe}, \mathrm{f}=333 \mathrm{H}_{\mathrm{z}}$, and $\mathrm{x}=0.2$.

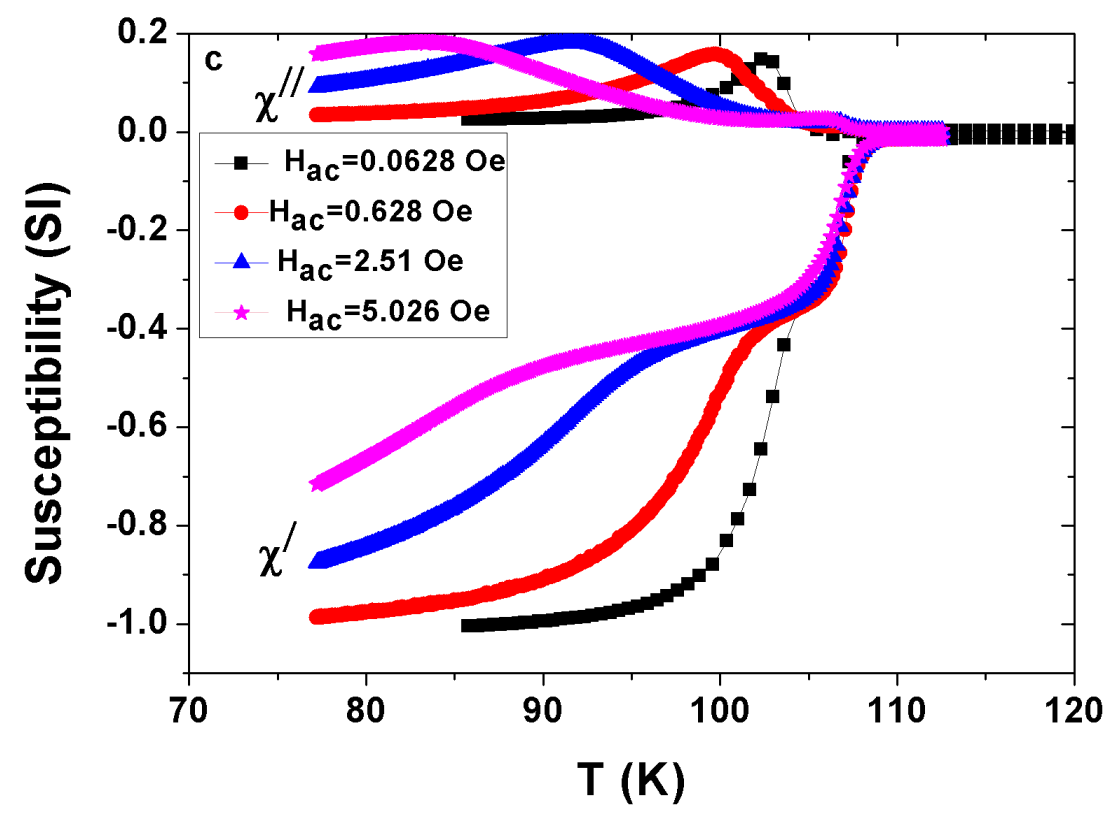

Fig. 4c: Temperature dependence of the magnetic susceptibility under different ac magnetic fields, $\mathrm{x}=0.2, \mathrm{f}=333 \mathrm{H}_{\mathrm{z}}$, and an annealing time of $48 \mathrm{~h}$. 


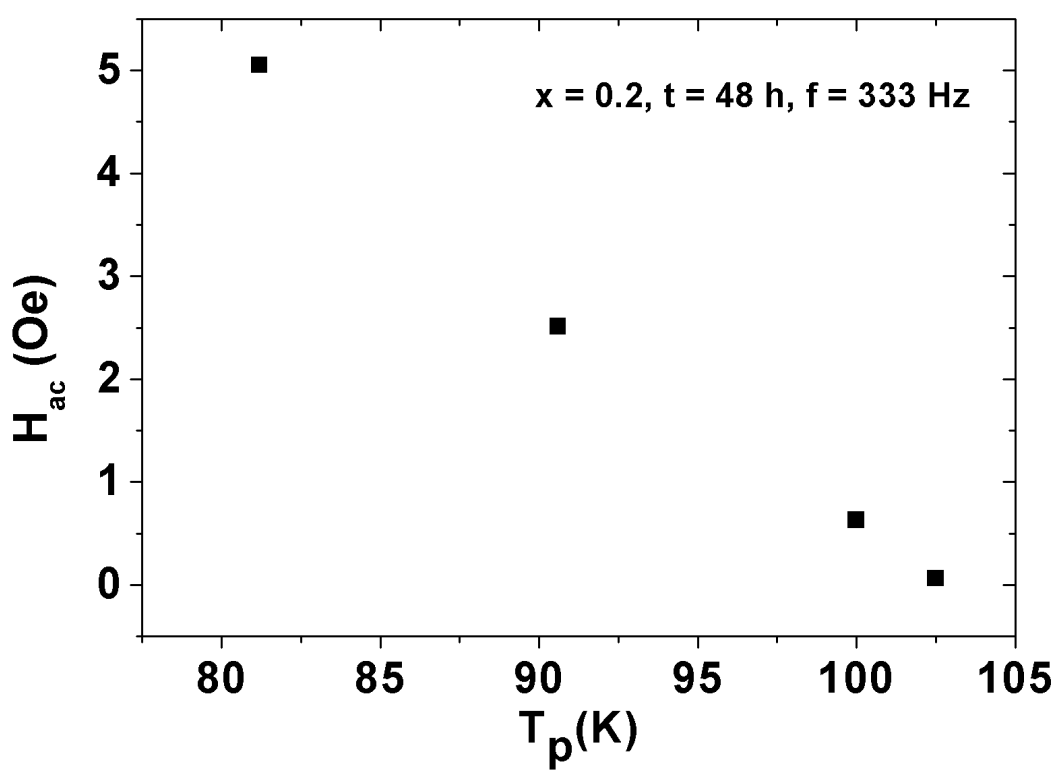

Fig. 5: Plot of ac magnetic field $\left(\mathrm{H}_{\mathrm{ac}}\right)$ vs. peak temperature $\left(\mathrm{T}_{\mathrm{p}}\right)$.

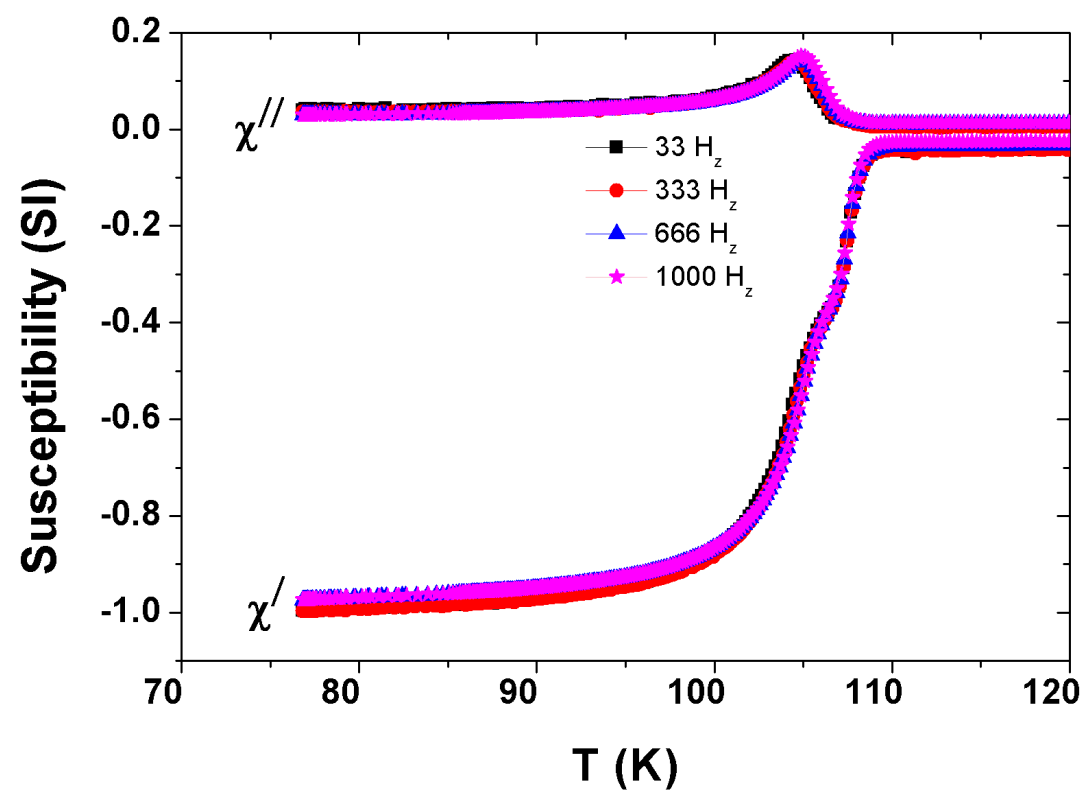

Fig. 6: Temperature dependence of the ac magnetic susceptibility under different frequencies, $\mathrm{H}_{\mathrm{ac}}=0.0628 \mathrm{Oe}, \mathrm{f}=333 \mathrm{H}_{\mathrm{z}}$, and an annealing time $0 \mathrm{f} 48 \mathrm{~h}$. 


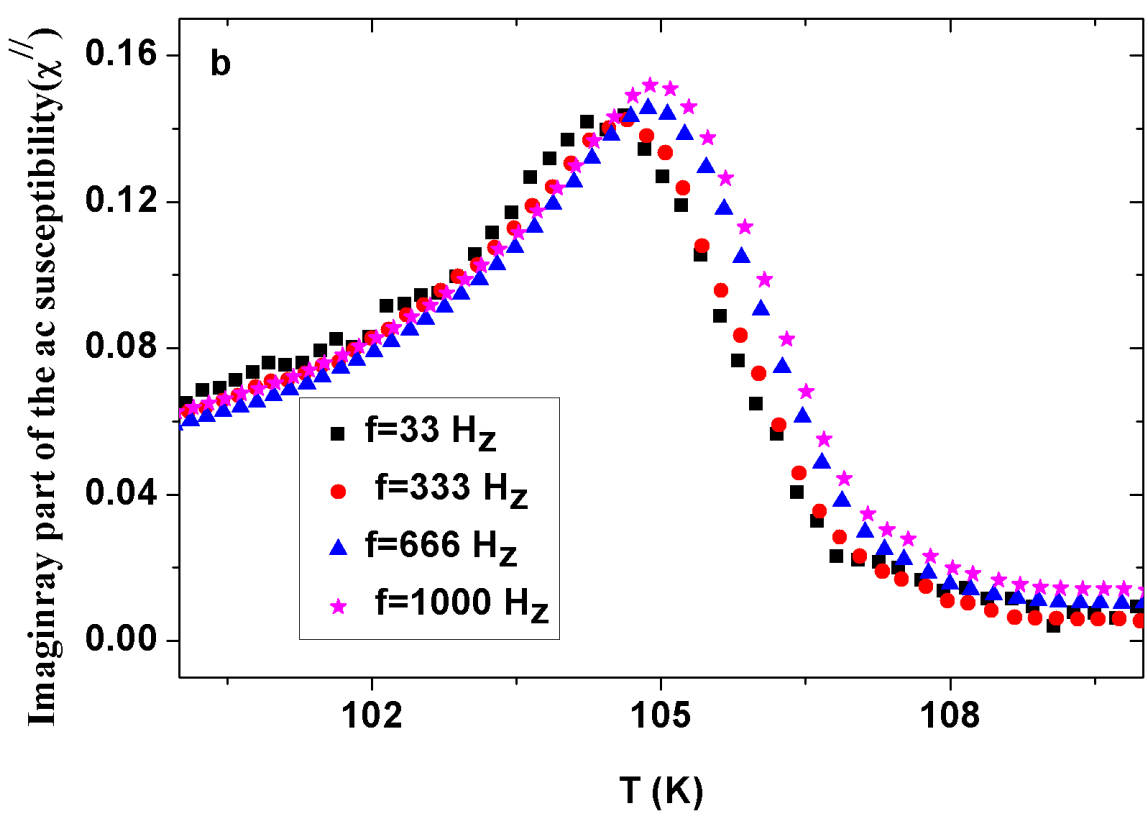

Fig. 7a: Temperature dependence of imaginary part of the ac magnetic susceptibility under different frequencies

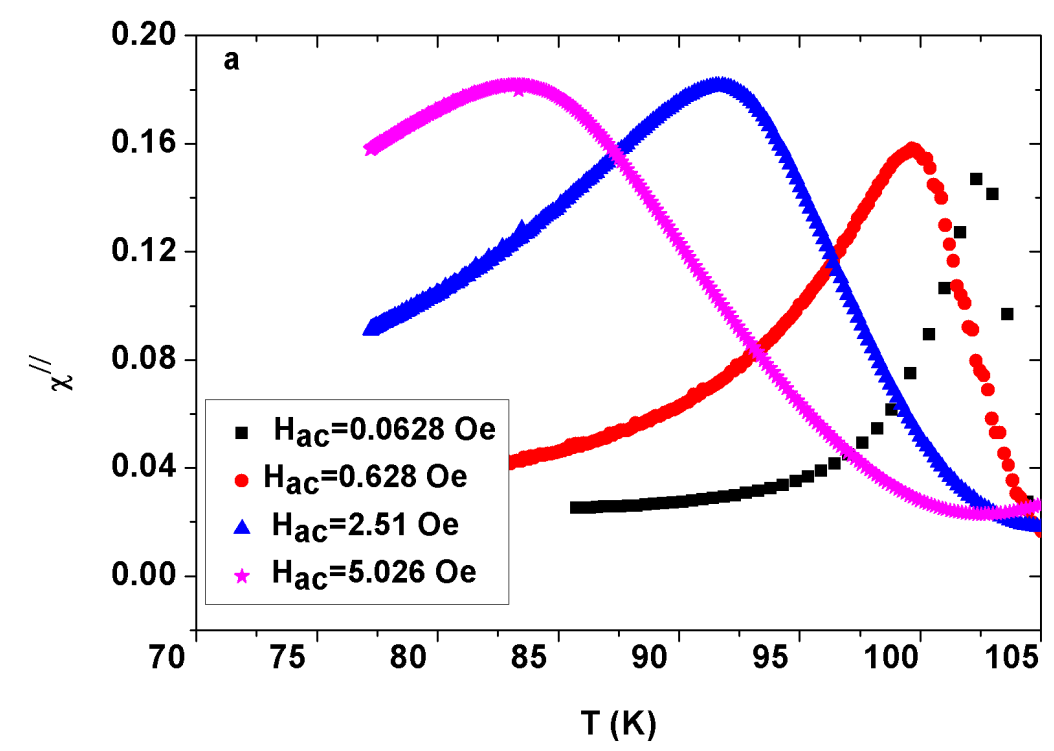

Fig. 7b: Temperature dependence of imaginary part of the ac magnetic susceptibility under different ac magnetic fields, $\mathrm{x}=0.2, \mathrm{f}=333 \mathrm{H}_{\mathrm{z}}$, and an annealing time of $48 \mathrm{~h}$. 


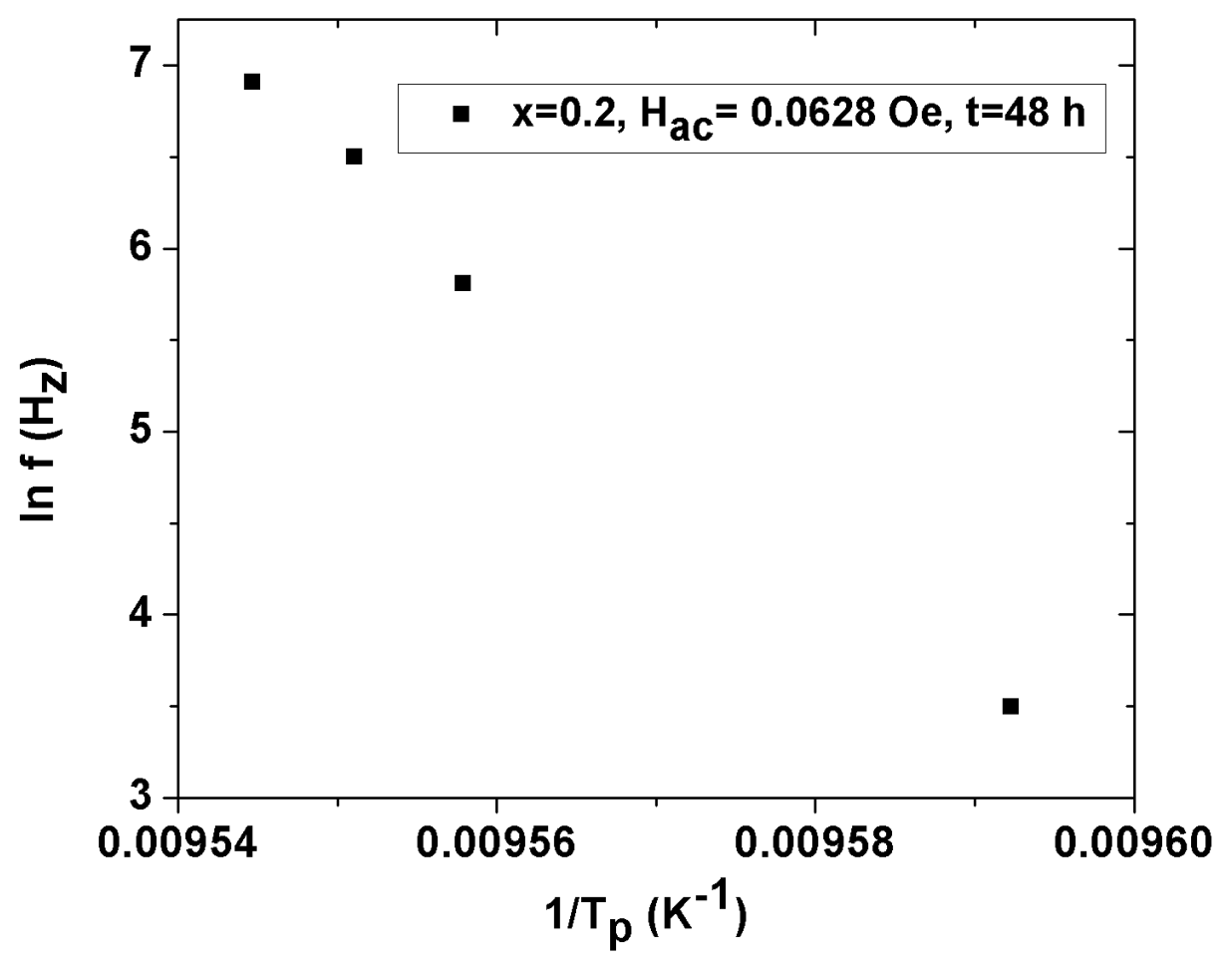

Fig. 8: Plot of $\ln \mathrm{f}$ vs. $1 / \mathrm{T}_{\mathrm{p}}$. 
Table 1: Relative volume fractions of $\mathrm{Bi}-2223, \mathrm{Bi}-2212, \mathrm{Bi}-2201$, and $\mathrm{PbO}$ of $\mathrm{Bi}_{1.6} \mathrm{~Pb}_{0.4} \mathrm{Sr}_{2-\mathrm{x}} \mathrm{Ba}_{\mathrm{x}} \mathrm{Ca}_{2} \mathrm{Cu}_{3} \mathrm{O}_{\mathrm{y}}$ samples with an annealing time of $\mathrm{t}=32 \mathrm{~h}$.

\begin{tabular}{|c|c|c|c|}
\hline $\mathrm{x}$ & 0.1 & 0.2 & 0.25 \\
\hline $\mathrm{Bi}-2223$ & 39.88 & 62.94 & 54.64 \\
\hline $\mathrm{Bi}-2212$ & 48.26 & 15.38 & 21.72 \\
\hline $\mathrm{Bi}-2201$ & 11.86 & 14.40 & 16.09 \\
\hline $\mathrm{PbO}$ & 0.0 & 7.28 & 7.55 \\
\hline
\end{tabular}

Table 2: Relative volume fractions of $\mathrm{Bi}-2223, \mathrm{Bi}-2212, \mathrm{Bi}-2201, \mathrm{BaBiO}_{3}$ and $\mathrm{PbO}$ of $\mathrm{Bi}_{1.6} \mathrm{~Pb}_{0.4} \mathrm{Sr}_{2-\mathrm{x}} \mathrm{Ba}_{\mathrm{x}} \mathrm{Ca}_{2} \mathrm{Cu}_{3} \mathrm{O}_{\mathrm{y}}$ samples with an annealing time of $\mathrm{t}=48 \mathrm{~h}$.

\begin{tabular}{|c|c|c|c|c|}
\hline $\mathrm{x}$ & 0.0 & 0.1 & 0.2 & 0.25 \\
\hline $\mathrm{Bi}-2223$ & 43.15 & 44.07 & 69.01 & 55.09 \\
\hline $\mathrm{Bi}-2212$ & 44.49 & 42.10 & 18.93 & 27.14 \\
\hline $\mathrm{Bi}-2201$ & 7.54 & 7.26 & 4.02 & 7.91 \\
\hline $\mathrm{PbO}$ & 4.82 & 6.57 & 7.28 & 7.88 \\
\hline $\mathrm{BaBiO}_{3}$ & 0.0 & 0.0 & 1.76 & 1.98 \\
\hline
\end{tabular}

Table 3: Relative volume fractions of $\mathrm{Bi}-2223, \mathrm{Bi}-2212, \mathrm{Bi}-2201$, and $\mathrm{PbO}$ of $\mathrm{Bi}_{1.6} \mathrm{~Pb}_{0.4} \mathrm{Sr}_{2-\mathrm{x}} \mathrm{Ba}_{\mathrm{x}} \mathrm{Ca}_{2} \mathrm{Cu}_{3} \mathrm{O}_{\mathrm{y}}$ samples with an annealing time of $\mathrm{t}=64 \mathrm{~h}$.

\begin{tabular}{|c|c|c|c|}
\hline $\mathrm{x}$ & 0.1 & 0.2 & 0.25 \\
\hline $\mathrm{Bi}-2223$ & 21.56 & 40.34 & $37 / 47$ \\
\hline $\mathrm{Bi}-2212$ & 44.88 & 39.69 & 33.17 \\
\hline $\mathrm{Bi}-2201$ & 27.08 & 14.11 & 23.23 \\
\hline $\mathrm{PbO}$ & 6.49 & 5.86 & 6.13 \\
\hline
\end{tabular}

Table 4: Lattice Parameters of $\mathrm{Bi}_{1.6} \mathrm{~Pb}_{0.4} \mathrm{Sr}_{2-x} \mathrm{Ba}_{x} \mathrm{Ca}_{2} \mathrm{Cu}_{3} \mathrm{O}_{\mathrm{y}}$ samples with an annealing time of $\mathrm{t}=48 \mathrm{~h}$.

\begin{tabular}{|c|c|c|c|c|}
\hline $\mathrm{x}$ & 0.0 & 0.1 & 0.2 & 0.25 \\
\hline $\mathrm{a}(\AA)$ & 5.4065 & 5.4296 & 5.4068 & 5.4617 \\
\hline $\mathrm{b}(\AA)$ & 5.3951 & 5.3814 & 5.3948 & 5.3035 \\
\hline $\mathrm{c}(\AA)$ & 30.4954 & 36.6711 & 37.0255 & 37.0851 \\
\hline
\end{tabular}

Table 5: Lattice parameters of $\mathrm{Bi}_{1.6} \mathrm{~Pb}_{0.4} \mathrm{Sr}_{2-\mathrm{x}} \mathrm{Ba}_{\mathrm{x}} \mathrm{Ca}_{2} \mathrm{Cu}_{3} \mathrm{O}_{\mathrm{y}}$ samples with a $\mathrm{Ba}$ content of $\mathrm{x}$ $=0.2$

\begin{tabular}{|c|c|c|c|}
\hline $\mathrm{t}(\mathrm{h})$ & 32 & 48 & 64 \\
\hline $\mathrm{a}(\AA)$ & 5.4208 & 5.4068 & 5.4178 \\
\hline $\mathrm{b}(\AA)$ & 5.3712 & 5.3948 & 5.4823 \\
\hline $\mathrm{c}(\AA)$ & 36.9396 & 37.0255 & 36.9078 \\
\hline
\end{tabular}


Figures

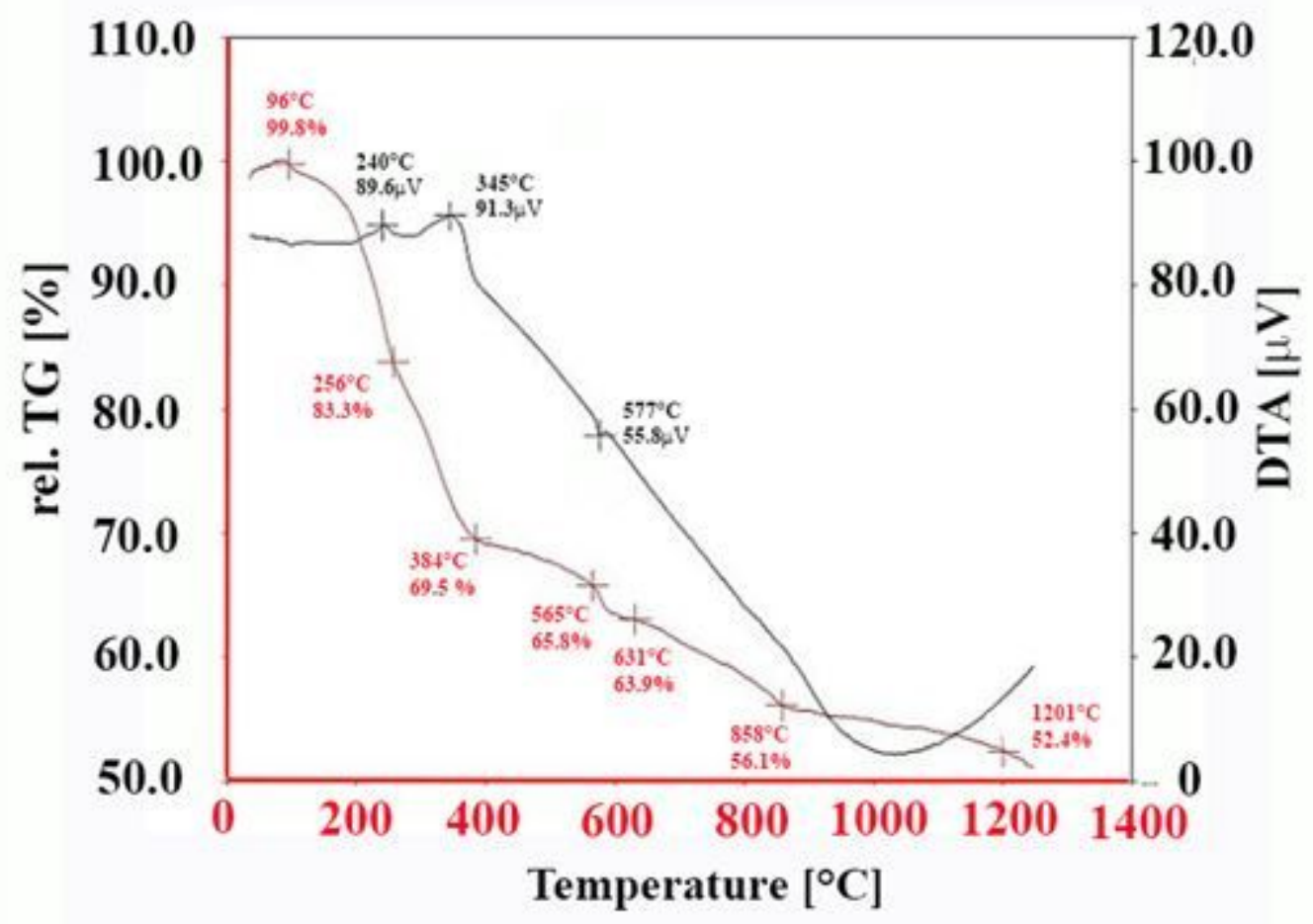

Figure 1

TGA and TDA curves for the gel dried at 110 .

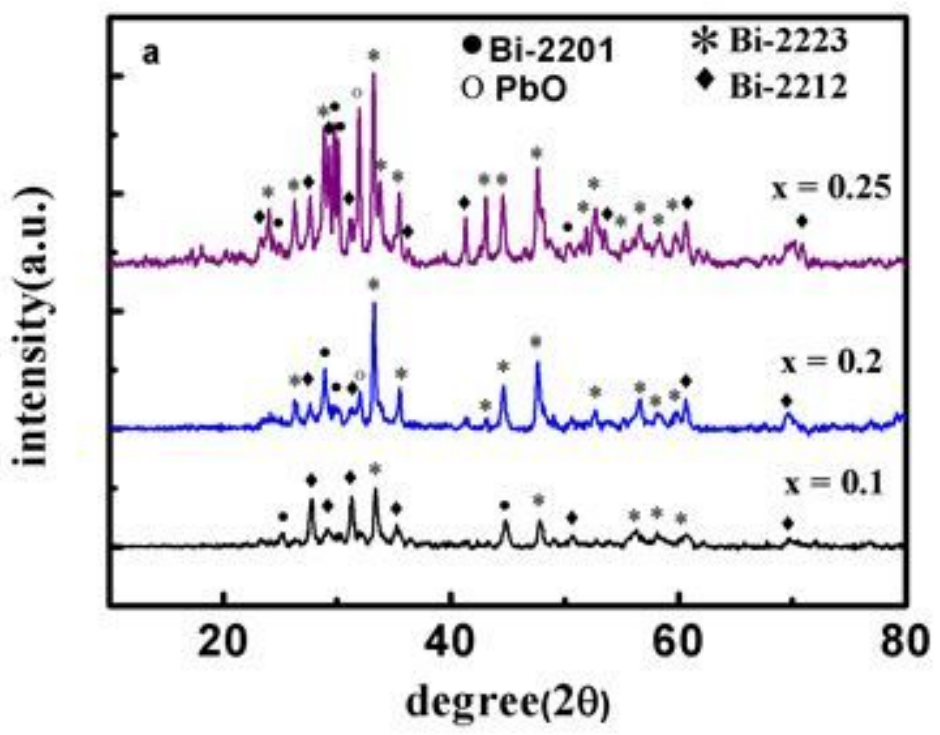

Figure 2

XRD patterns of samples with Ba contents of $x=0.1,0.2,0.25$, and an annealing time of $32 \mathrm{~h}$. 


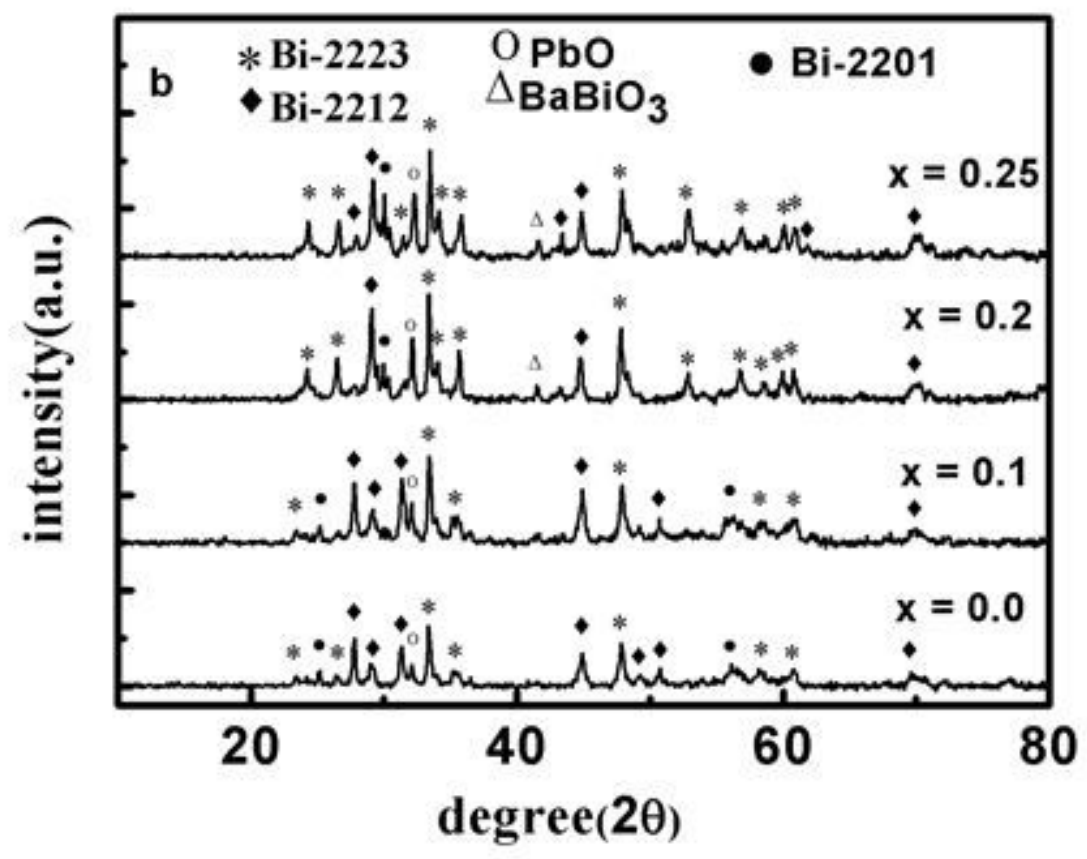

Figure 3

XRD patterns of samples with Ba contents of $x=0.0,0.1,0.2,0.25$, and an annealing time of $48 \mathrm{~h}$.

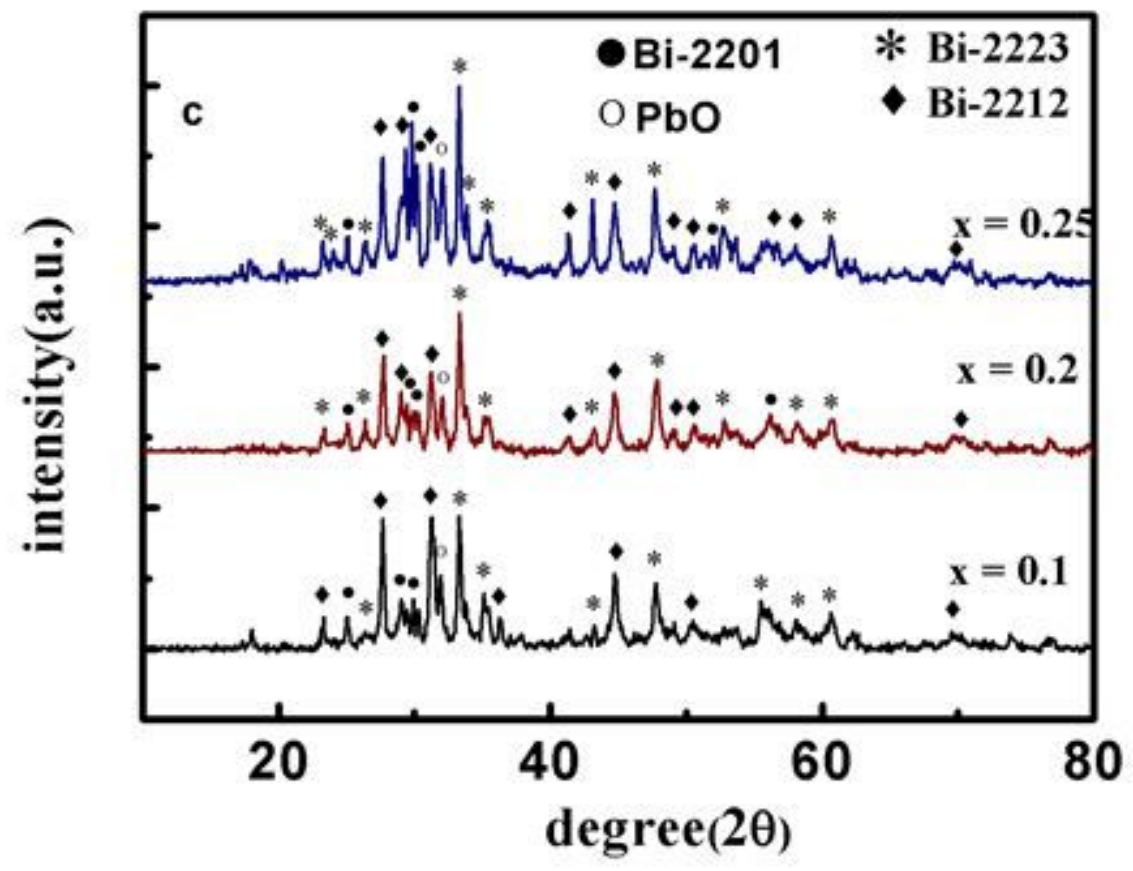

Figure 4

XRD patterns of samples with Ba contents of $x=0.1,0.2,0.25$, and an annealing time of $64 \mathrm{~h}$. 

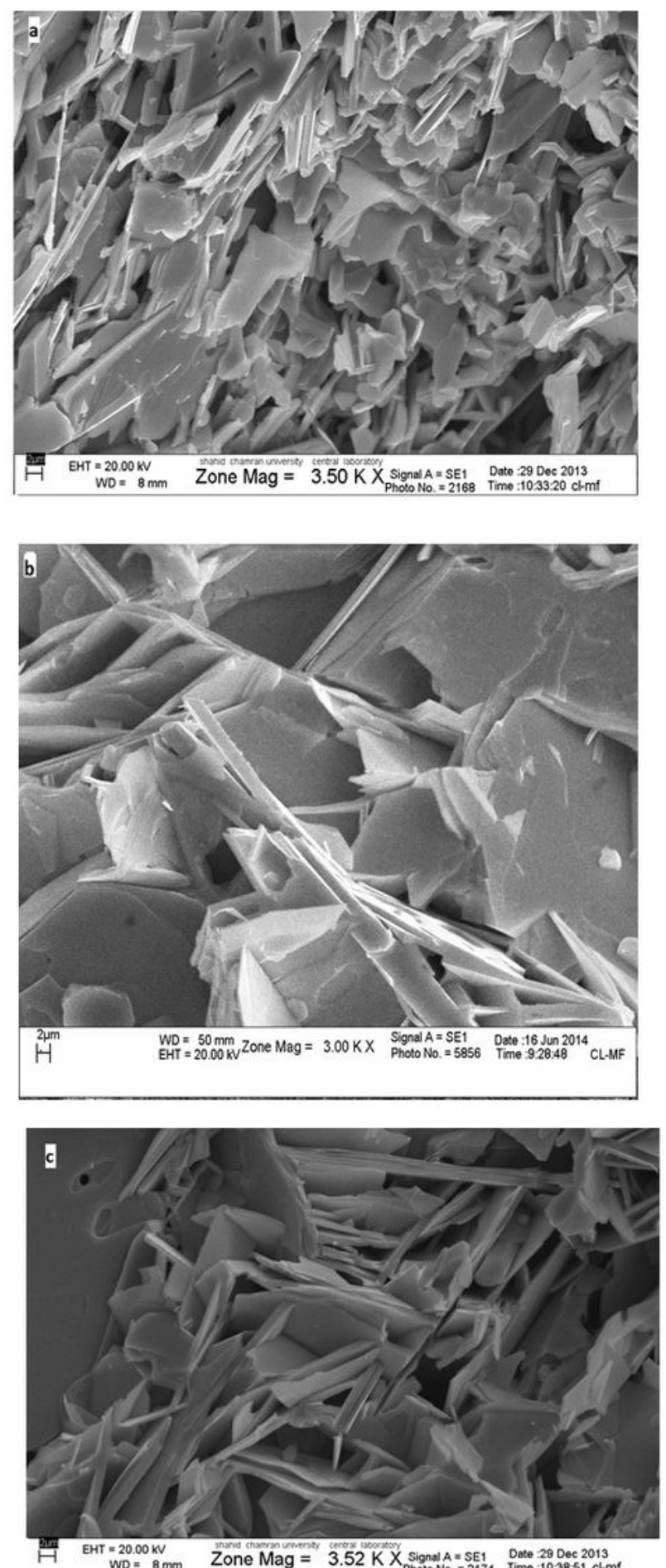

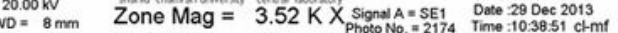

\section{Figure 5}

The SEM micrographs of samples with different amounts of Ba: a) $0.0, b) 0.2$, and c) 0.3 with annealing time of $48 \mathrm{~h}$. 


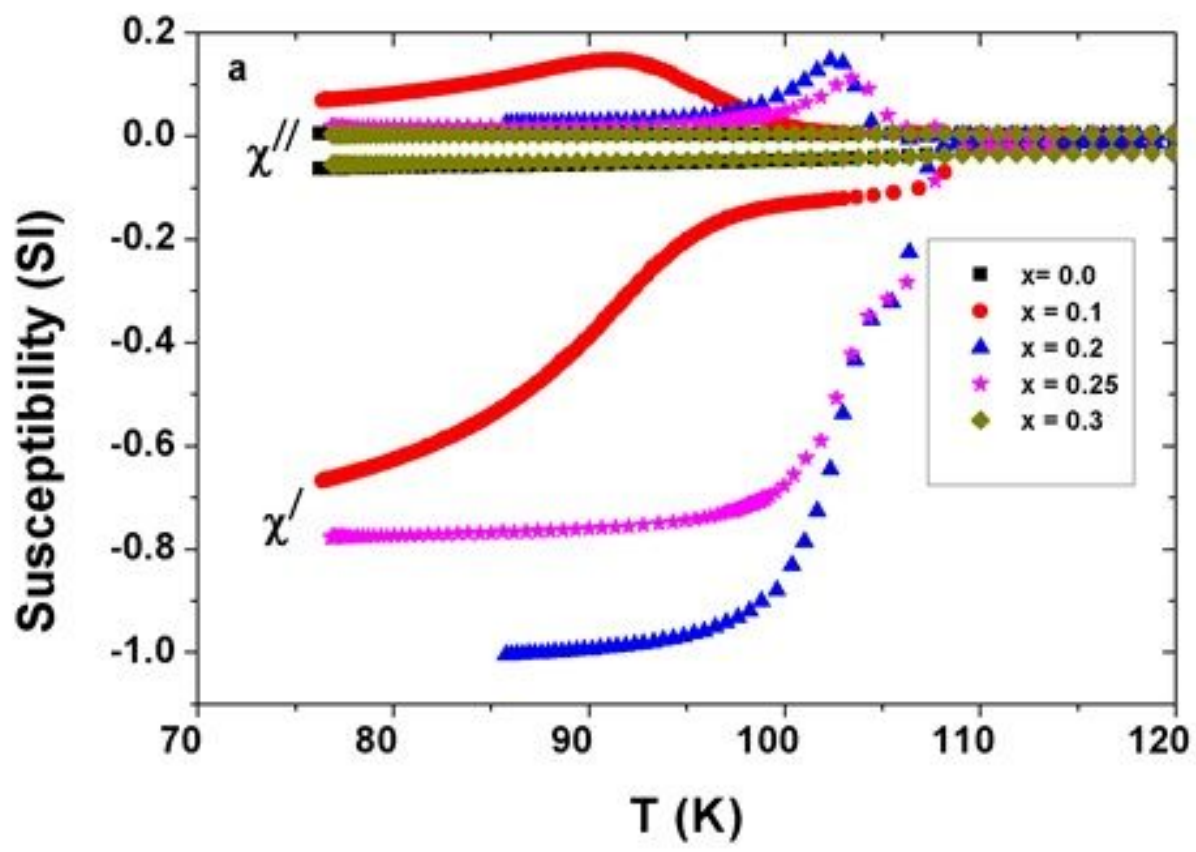

Figure 6

Temperature dependence of the magnetic susceptibility for samples with different $\mathrm{Ba}$ contents, $\mathrm{Hac}=$ $0.0628 \mathrm{Oe}, \mathrm{f}=333 \mathrm{~Hz}$, and an annealing tame of $48 \mathrm{~h}$.

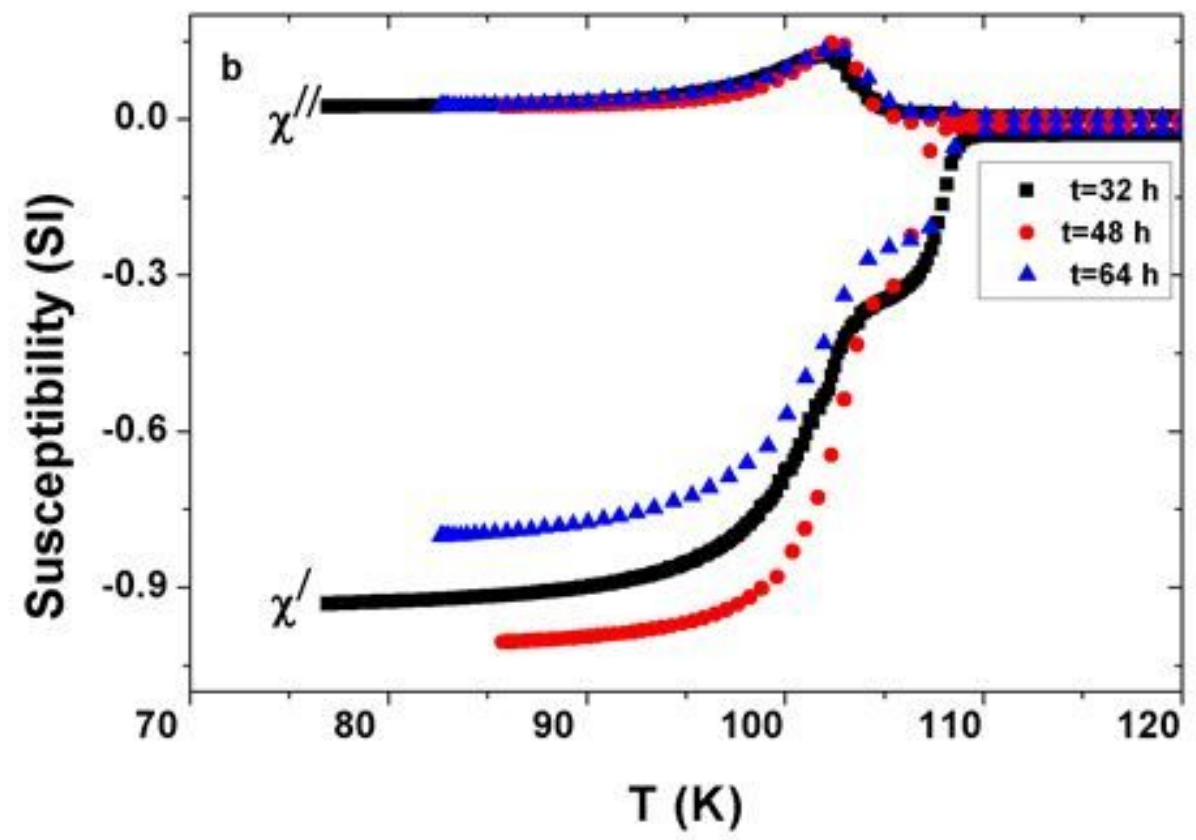

Figure 7

Temperature dependence of the magnetic susceptibility under different annealing times, $\mathrm{Hac}=0.0628 \mathrm{Oe}$, $f=333 \mathrm{~Hz}$, and $x=0.2$. 


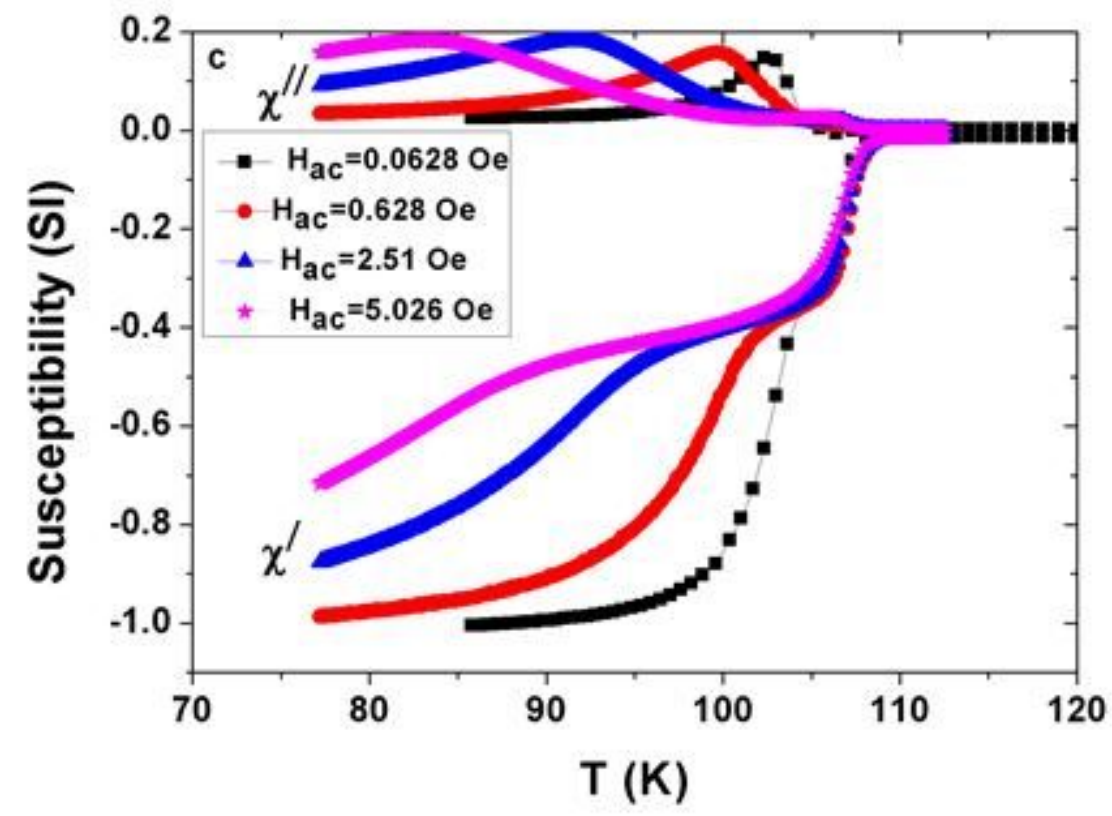

Figure 8

Temperature dependence of the magnetic susceptibility under different ac magnetic fields, $x=0.2, f=333$ $\mathrm{Hz}$, and an annealing time of $48 \mathrm{~h}$.

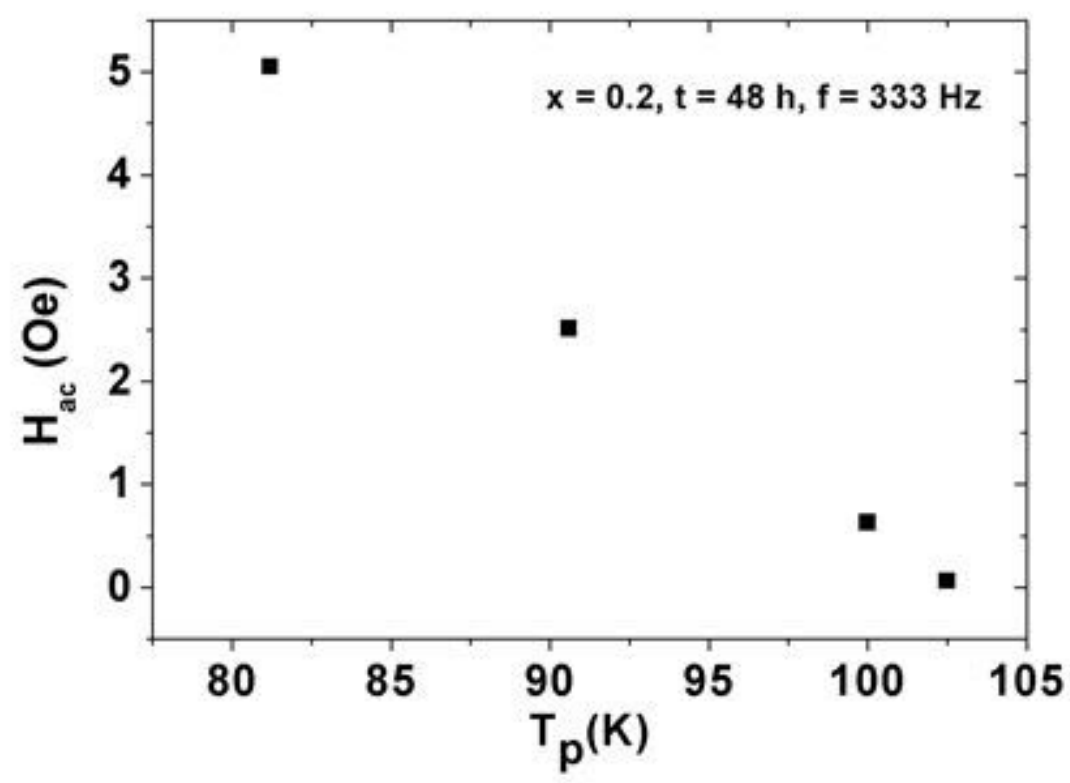

Figure 9

Plot of ac magnetic field (Hac) vs. peak temperature (Tp). 


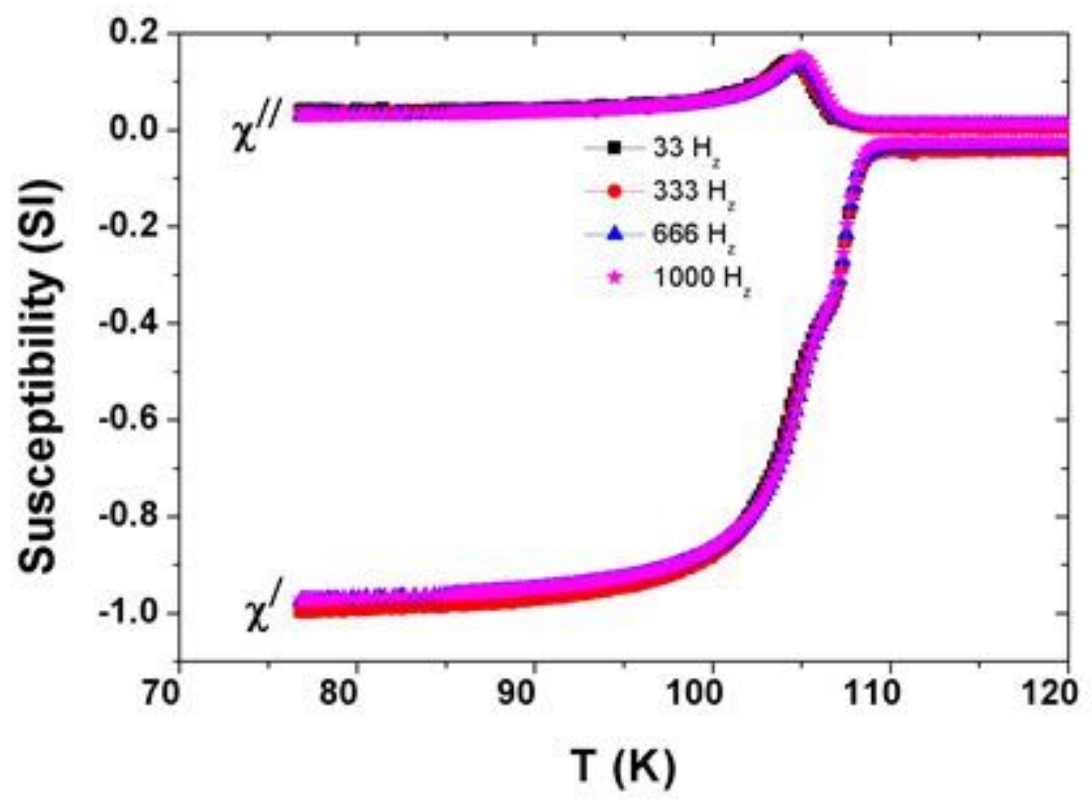

Figure 10

Temperature dependence of the ac magnetic susceptibility under different frequencies, $\mathrm{Hac}=0.0628 \mathrm{Oe}, \mathrm{f}$ $=333 \mathrm{~Hz}$, and an annealing time of $48 \mathrm{~h}$.

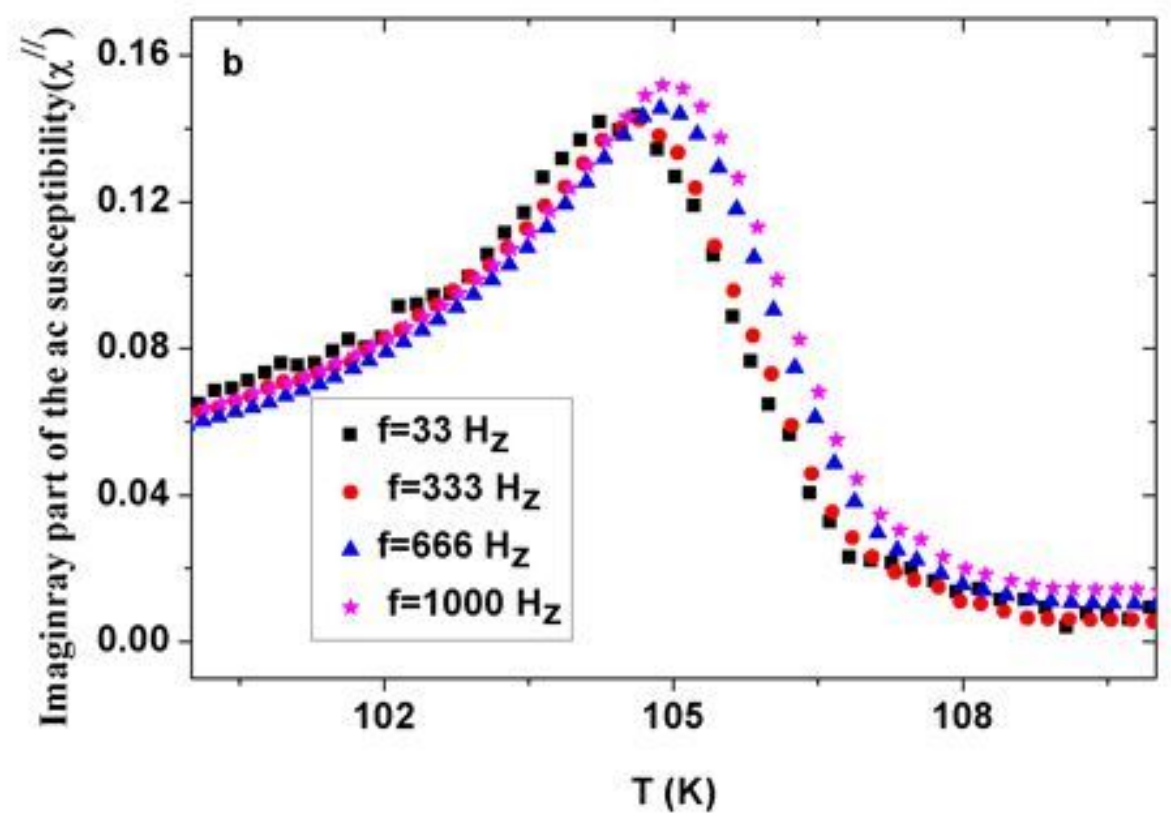

Figure 11

Temperature dependence of imaginary part of the ac magnetic susceptibility under different frequencies 


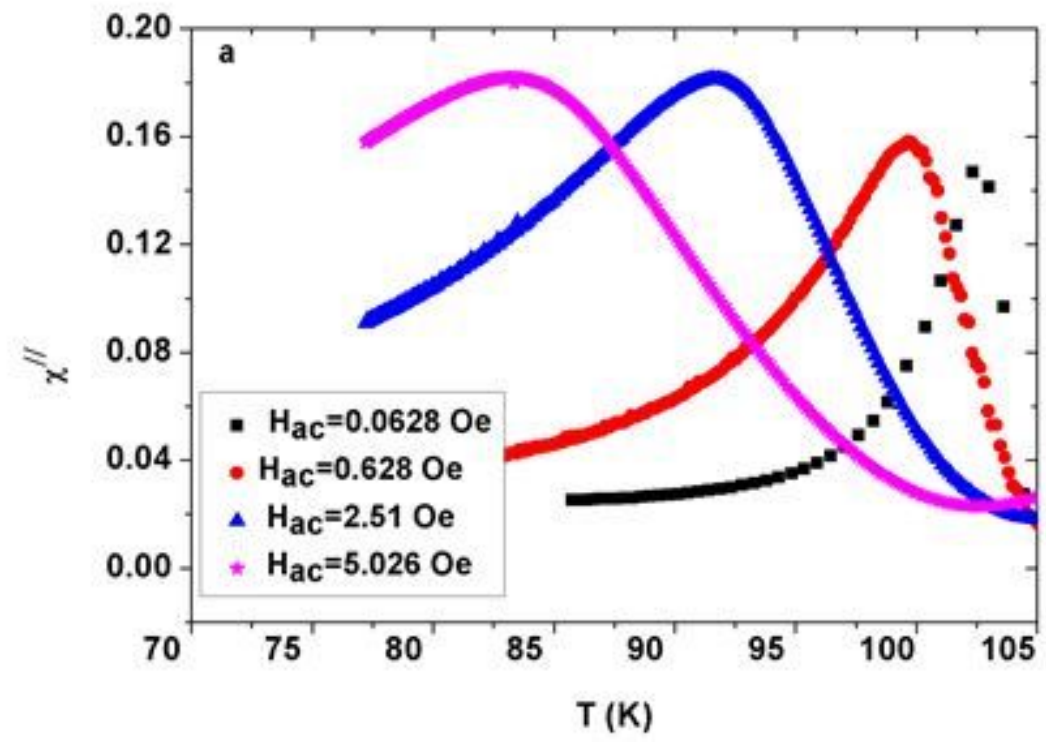

Figure 12

Temperature dependence of imaginary part of the ac magnetic susceptibility under different ac magnetic fields, $x=0.2, f=333 \mathrm{~Hz}$, and an annealing time of $48 \mathrm{~h}$.

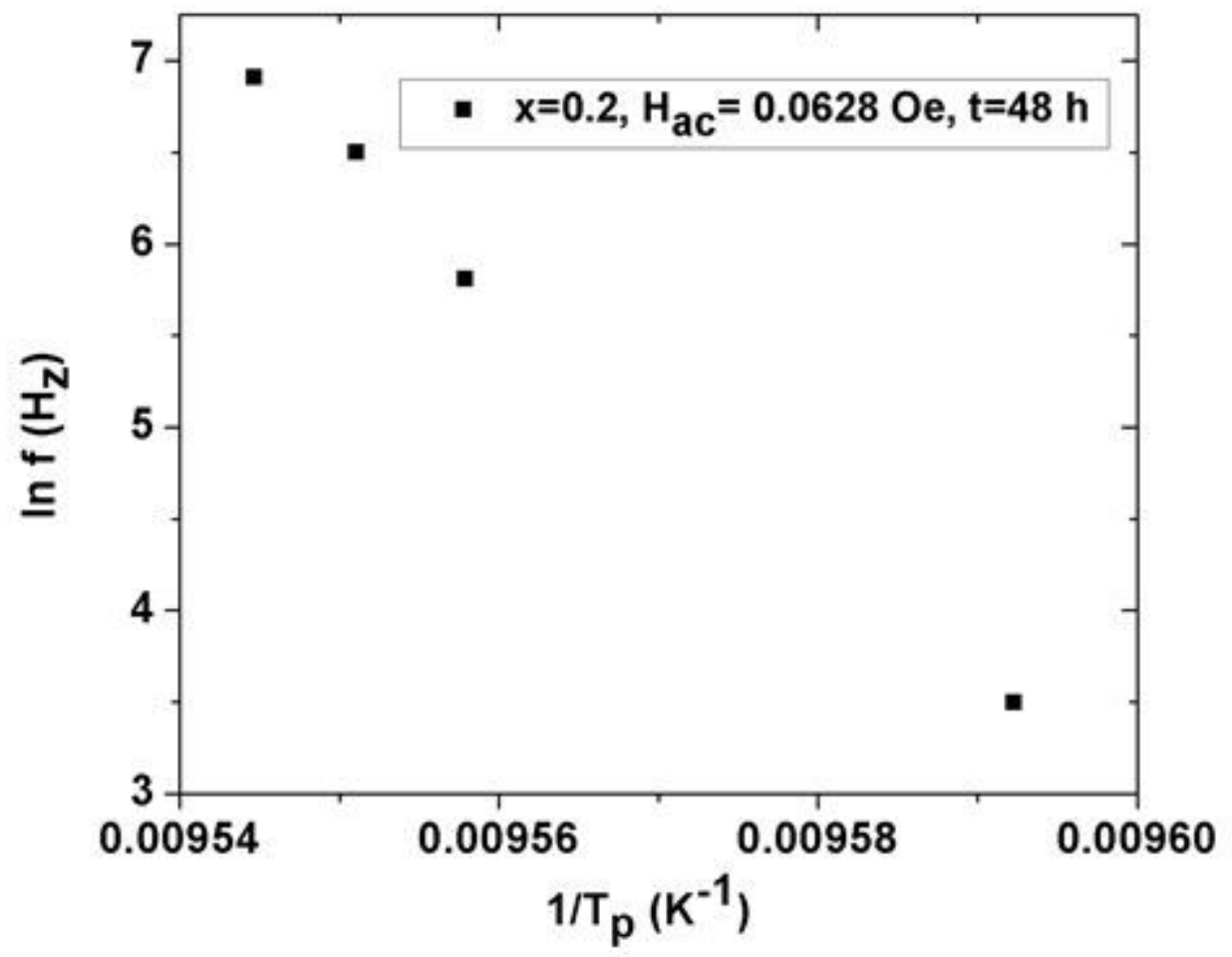

Figure 13

Plot of In $f$ vs. $1 /$ Tp. 